\title{
Bullying and Its Relationship to Social Behavior among Intermediate Students
}

\author{
Mohammed Zuhair Hussein Janjon \\ Ministry of Education / Open Educational College \\ Mohammedjanjon@yahoo.com
}

\begin{abstract}
The current research measures the following:

1. Bullying among middle intermediate students.

2. Social behavior among intermediate students.

3. The relationship between bullying and social behavior among intermediate students.

In order to achieve the objectives of the research, the researcher did the following: Prepare the scale of bullying and adopt a measure of social behavior, which culminated in the final form after the completion of the conditions of honesty and consistency and the discrimination of paragraphs (20) of the scale of bullying and (46) of the measure of social behavior, and identify the research students middle and secondary stage of males In the General Directorate for the education of Babylon for the academic year 2017-2018, and consists of the research community of (2600) students, and the research adopted the descriptive approach, and to achieve the research objectives applied researcher scale bullying and the measure of social behavior on the sample of the research, and then analyzed the data using the program bag statistical high Social data processing (SPSS) and the results were as follows:

1. intermediate students suffer from a high level of bullying.

2. Low level of social behavior among intermediate students.

3. There is a weak correlation between the level of bullying and social behavior

According to the results of the research, some recommendations and proposals were presented.
\end{abstract}

Keywords: bullying, social behavior. 


\section{التنمر وعلاقته بالسلوك الاجتماعي لاى طلبة المرحلة المتوسطة \\ محمد زهير حسين جنجون \\ وزارة التتربية/ الكلية التتربوية الدفتوحة}

Mohammedjanjon@yahoo.com

$$
\text { ا-بستهدف البحث الحالي قياس ما يأتي: }
$$

r- السلوك الاجتماعي لدى الطلبة المرحلة المتوسطة.

ب-العلاقة بين التتمر و السلوك الاجتماعي لدى الطلبة المرحلة المتوسطة.

ولغرض تحقيق اهداف البحث قام الباحث بما يأتي: اعداد مقياس التنمر وتبني مقياس السلوك الاجتماعي الذان تألفا بصيغتهما النهائية بعد اكتمال شروط الصدق و الثبات وتمييز الفقرات (· ب) فقرة لمقياس التتمر و(7) فقرة لمقياس السلوك الاجتماعي, وتحدد البحث بطلبة المرحلة المنوسطة والثانوية من الذكور

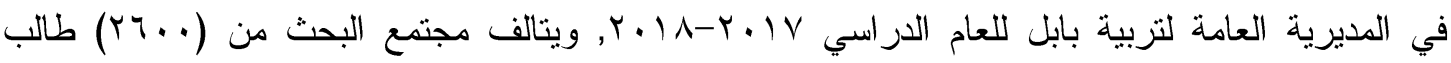
وطالبة, واعتمد البحث المنهج الوصفي, وتحقيقا لاهداف البحث طبق الباحث مقياس التنمر ومقياس السلوك الاجتماعي على عينة البحث, ثم حلت البيانات بالاستعانة ببرنامج الحقيبة الاحصائيه للعلوم الاجتماعية في لائي

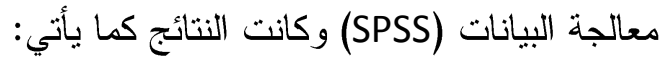

1-ان الطلبة المرحلة المتوسطة يعانون من مستوى مرتقع من التنمر . r-انخفاض مستوى السلوك الاجتماعي لدى طلبة المرحلة المتوسطة. r-وجود علاقة ارتباطية ضعيفة بين مستوى التتمر و السلوك الاجتماعي. وطبقا للنتائج التي توصل اليها البحث قدمت بعض التوصيات و المقترحات الكلمات الدالة: التتمر , السلوك الاجتماعي.

\section{الفصل الاول/ التعريف بالبحث/ المقدمة}

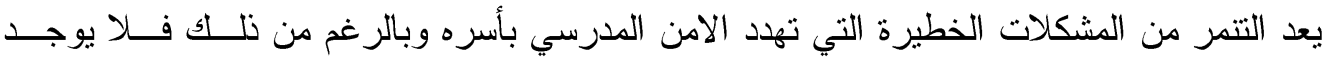
الاهتمام الامثل بهذه المشكلة في المجتمعات العربية عامة و المجتمع العر اقي خاصة. سو اء من حيث انتشارها اوعلى مستوى الحد منها أو معالجتها في حين نجد التزاث السيكولوجي الغربي قد اعطى هذه وهن المشكلة اهنماما

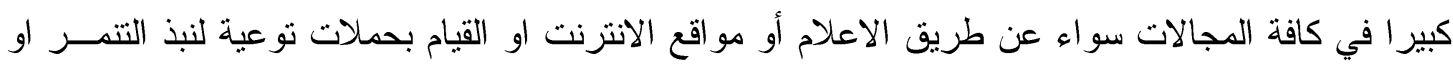


من حيث علاقة هذه المشكلة بمتغير ات اخرى او اثار ها واسبابها و انتشار ها وتصميم العديــــــن البــر امج التنخليه لخفضها و التعامل معها. ولم نجد ذلك على المستوى العربي عامة و العر اقي خاصا.

ويعد التنمر مشكلة كبيرة لانه يؤذي الطلبة جسديا ونفسيا. وان وجود التنمر في الصــف الدراسـي

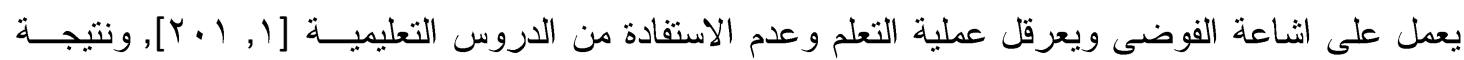

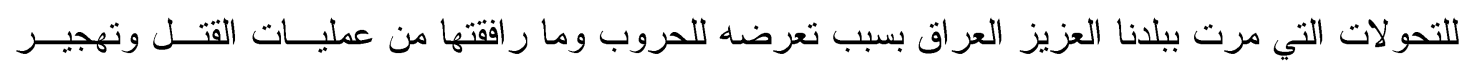

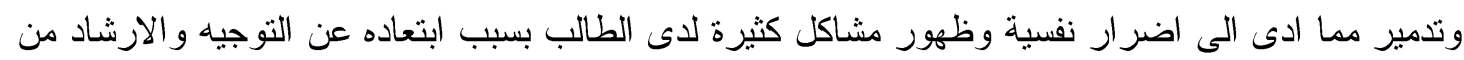

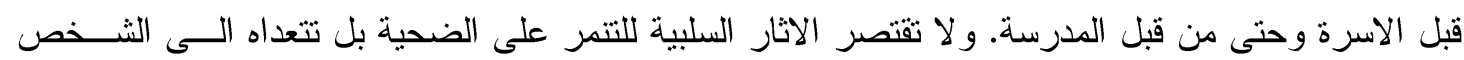
المتتمر حيث يعاني من مشكلة اخرى لدية هي السلوك الاجتماعي والتي تتمثل في عدم الانضباط الاجتماعي لإني

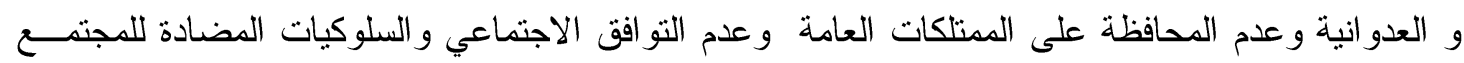

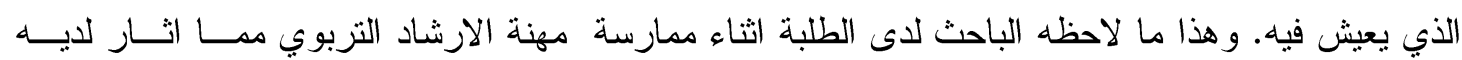

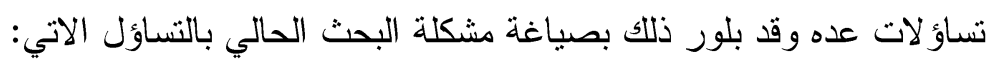
ما علاقة التتمر بالسلوك الاجتماعي لدى الطلبة المرحلة المتوسطة؟ ثانيا: الهية (لبحث: تتجلى اهمية البحث الحالي بالمحاور الاتية: أولا: الاهمية النظرية:

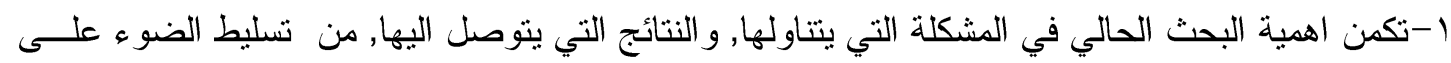

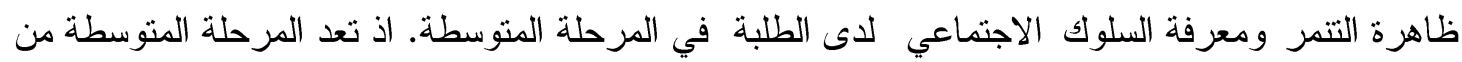

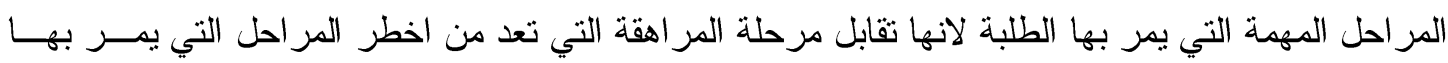

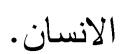

ץ-لاتوجد در اسة بين الدراسات - على حد علم الباحث - تتاولت ظاهرة التتمر وعلاقته بالسلوك الاجتمــاعي

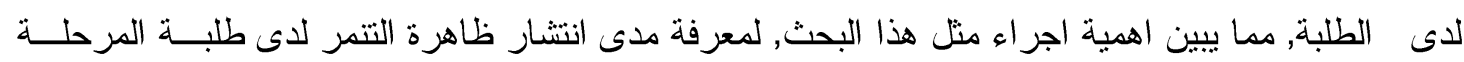
المتوسطة و امكانية وجود علاقة بينها وبين السلوك الاجتماعي لديهم. ץ-ان البحث يتجه نحو طلبة المرحلة المتوسطة وهم شريحة كبيرة في المجتمع, وهذا البحث تتجلى اهميته في ودئ

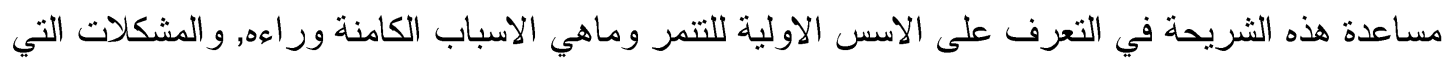

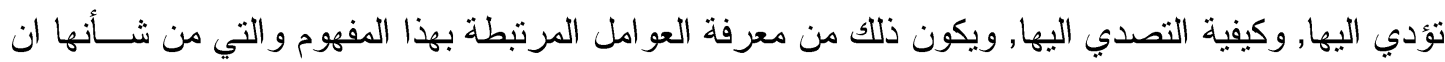

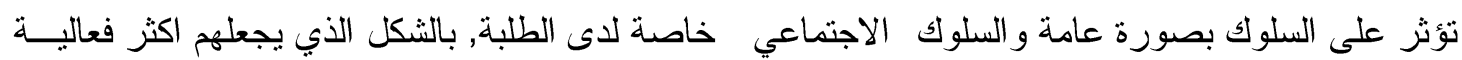
وحضور في حياتهم الاسرية والاجتماعية.

ثانيا: الاهمية التطبيقية العملية:

1-تتمثل الاهمية العملية لهذا البحث, و التي تهتم بشكل عام بطلبة وخاصة الطلبة المتتمرين, على اســاس ان

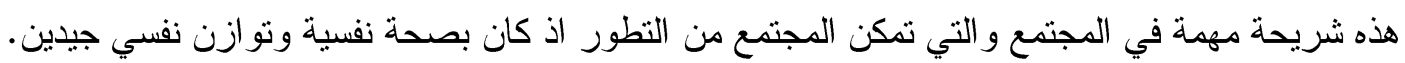

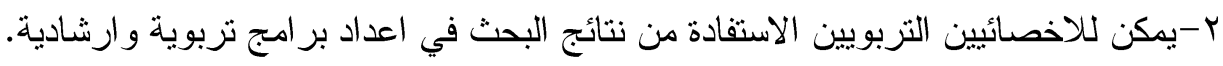


Journal of University of Babylon, Humanities, Vol.(26), No(6): 2018

ثالثا: أهداف البحث: يهدف البحث الحالي التعرف على:

ا-مستوى التتمر لدى طلبة المرحلة المتوسطة.

ץ-مستوى السلوك الاجتماعي لدى طلبة المرحلة المتوسطة.

ب-العلاقة بين التتمر و السلوك الاجتماعي لدى طلبة المرحلة المتوسطة.

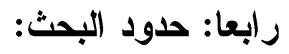

1- الحدود البشرية: طلبة المرحلة المتوسط من الذكور.

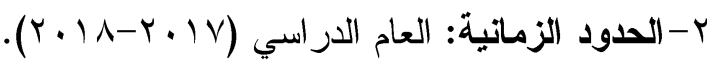

ب-الحدود المكانية: المدارس الثانوية و المتوسطة في مركز محافظة بابل.

ع - الحدود المعرفية: التنمر و السلوك الاجتماعي.

خامسا: تحديد المصطلحات:

أولا: التنمر: عرفه كل من: - أن

1-ميلور (Mellor, 1997): "بأنه عنف طويل المدى يقوم به فرد او مجموعة من الافر اد ضد فــرد غيــر

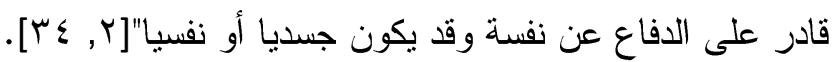

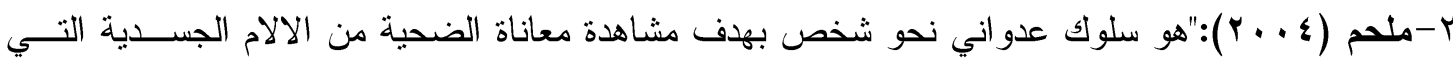
يتركها المعتدي عليه" [ب, 10] هو سله

r-سليمان و الببلاوي ( • ( ؟):" هو الهجوم من شخص مستأسد على شخص اضعف منه لديه تلذذ بمشاهدة

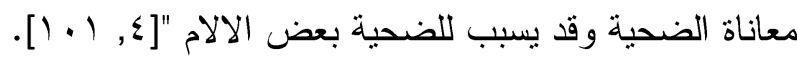
أما التعريف الاجر ائي للتتمر : الدرجة الكلية التي يحصل عليها افراد عينة البحث من اجاباتهم عن فقـرات مقياس التنمر المعد لهذا الغرض. ثانيا: السلوك الاجتماعي: عرفه كل من:1-منسي (911 (1): " كل نشاط يقوم به الفرد بحيث يكون منصلاً بفرد اخر او بافر اد آخرين، ويمكـن منـــه

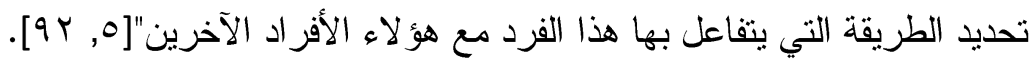

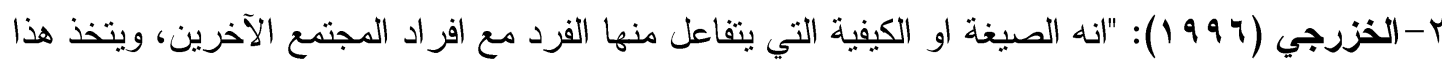

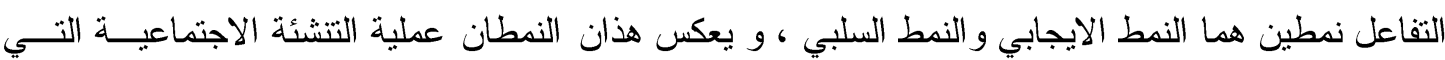

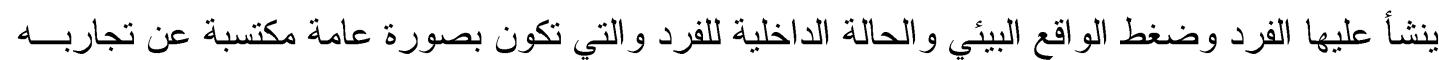

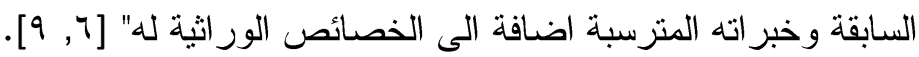

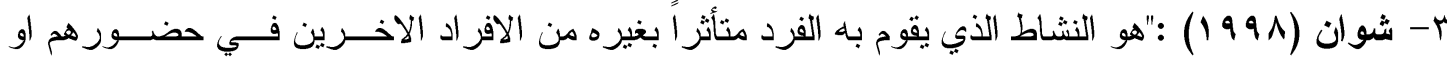

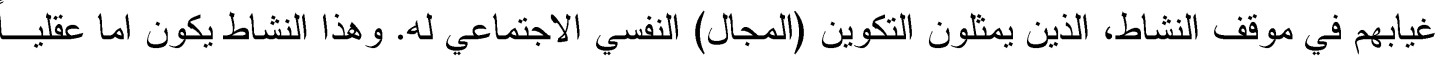

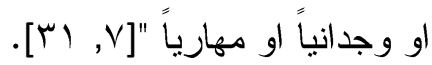


Journal of University of Babylon, Humanities, Vol.(26), No(6): 2018

ع- ذيب († . . ץ): هو نشاط بصدر عن الطالب كنتيجة لتفاعله مع ظروف بيئية تتعلق بالجامعة, ويتمثل ذلك في

محاو لاته المتكررة للتعديل او التغيير والتحسين في هذه الظروف حتى تنتاسب مع مقتضيات حياته [م, ه]. أما التعريف الاجر ائي للسلوك الاجتماعي: هي الدرجة الكلية التي يحصل عليها افر اد العينــة عـن طريسـق

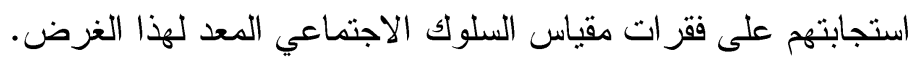
الفصل الثاني/ المحور الاول/ الاطار النظري:

(Bullying) أولا :التنمر)

أصبح التنمر اليوم مشكلة شائعه وخطيرة في المدارس, وتؤكد الابحاث على مدى الاثار السلبية التي

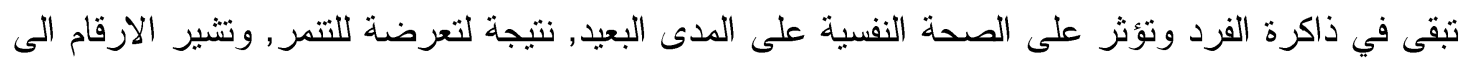

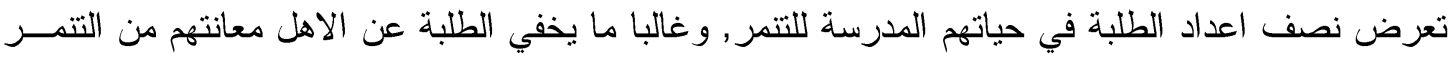

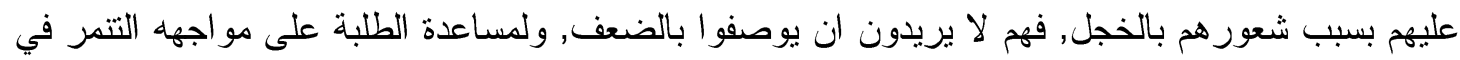

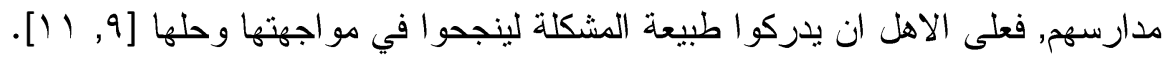
النظريات التي فسرت التنمر: لقد تباينت النظريات في تفسير سلوك التتمر فالنظرية التحليلية تؤكد بأنه نتاج التتاقض بين دافع الحيـاة و الموت وتحقيق اللذة عن طريق تعذيب الاخرين و عقابهر و التصدي لهم كي لا ينجحوا [ب , 14]. ويرى اصحاب النظرية السلوكية في تفسيرهم للسلوك العدواني بوصفه سلوكا قابلا للملاحظة و القياس, اذ أن علم النفس من وجهة نظرهم هو العلم الذي يدرس السلوك القابل للملاحظة و الذي يمكن اخضاعه للقياس

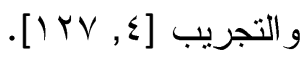

و عليه فان الفرد على وفق هذة النظرية امامه احتمالات لا حصر لها لاكتساب السلوك ويقوم الاباء فــي

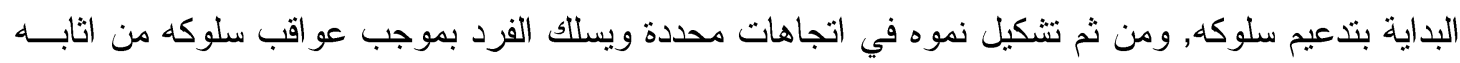

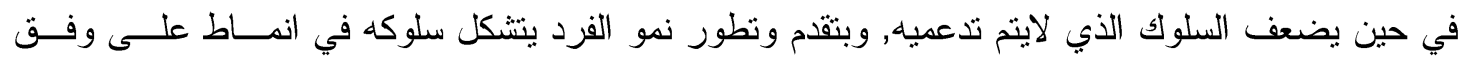
خبر اته التدعيمية.

ومما تجدر الاشارة اليه ان هذه النظرية مرت بمرحلتين في تفسير الســلوك العــدواني: المرحلـــة

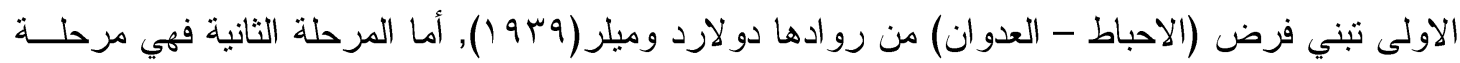

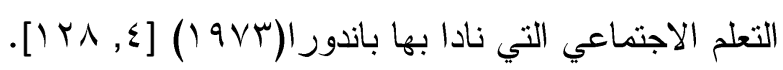
وتزى نظرية (الاحباط - العدوان) أن العدوان عادة مايكون نتيجة الاحبــاط, وان تعـرض الفــرد

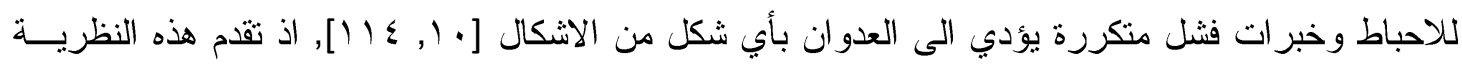

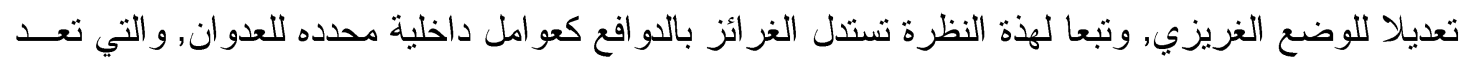

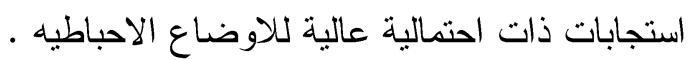
فالاحباط يحث دافع العدوان الذي بدوره يحول السلوك ليميل الى ايذاء الاخرين او تخريب ممتلكاتهم

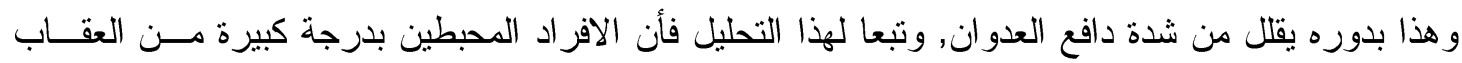


Journal of University of Babylon, Humanities, Vol.(26), No(6): 2018

الثنديد من الو الدين أو الفثل المستمر في المدرسة أو نقص العمل يتوقع ان يظهروا اسـتنياء وعدائيـة [1), $\cdot[r \cdot V$

ويشير دو لارد وميلر أن كل سلوك سواء كان غير مرغوب أو مرغـوب هـــو مــتعلم مــن الرغبــة

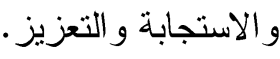

أما نظرية التعلم الاجتماعي تؤكد على الدور الذي تلعبه الملاحظة و النمذجة أو القدوة أو الخبــرات

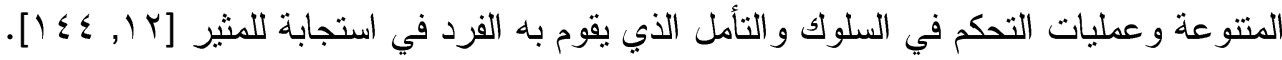

أن نظرية التعلم الاجتماعي نظرية سلوكية لا تعتمد التعزيز اعتمادا كليا وانما ترى ان سلوك الفــرد

يشكل بفعل تأثير الكبار وخاصة الاباء [با, سب]], وتثير الى ان التتمر هو حالة نمذجة لسلوك نموذج متتمر

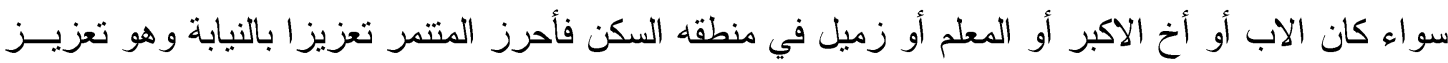

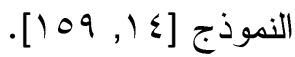

لقد افترض باندورا ان الافر اد يتعلمون السلوك عن طريق ملاحظة النماذج عن و الديهر ومدرسيهم و اصدقائهم ومن افلام التلفزيون و القصص التي يقرؤونها و الحكايات التي يسمعونها ويحصلون على نماذج السلوك التـي

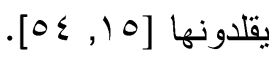

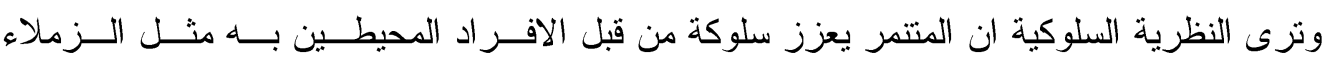

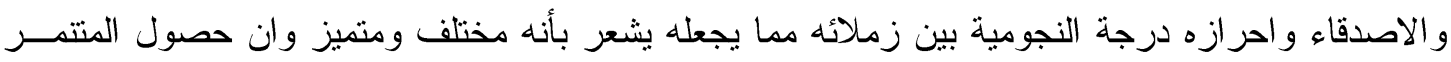

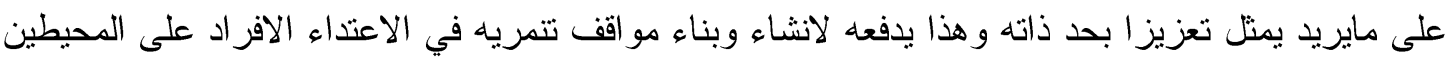

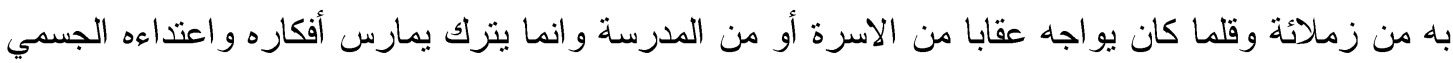

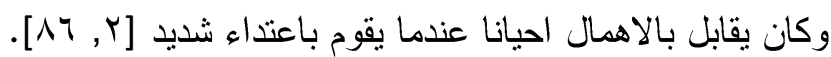

ان التعزيز يلعب دورا كبير ا في التعبير عن العدوان فلننظر اولا الى دور التعزيز الايجــابي وهـــ النتائج المرضية الني تزيد من تكرار السلوك اذ وجد ان الافر اد بامكانهم الوصول الى الى اول الصف لفئ (الطابور )

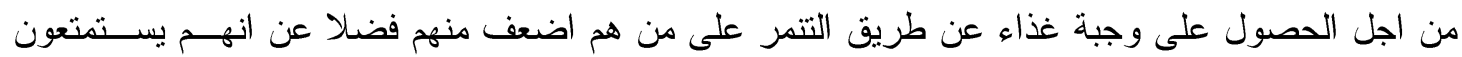

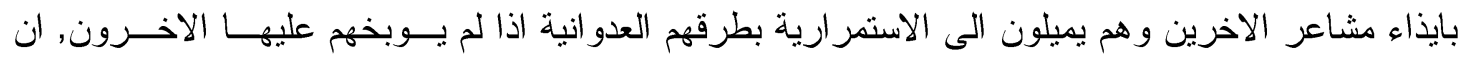

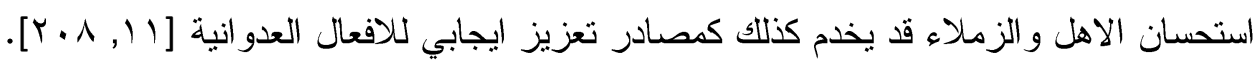
وتشير بعض النظريات الى ان الافراد يتعلمون العنف عن طريق الثواب و العقــاب وعـن طريـق

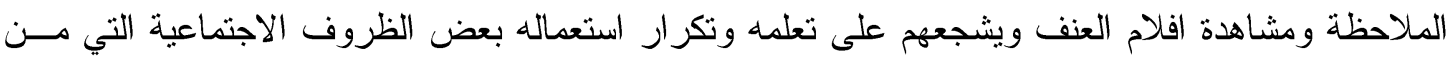
اهمها:

1-عدم الحزم في الاخذ على ايدي المعتدين وعدم الالتز ام بتطبيق القو انين و الثرائع الرادعة تجعلهم يجنون ثمار عدو انهم ويعزز سلوكهم فيكررونه في مو اقف كثيرة.

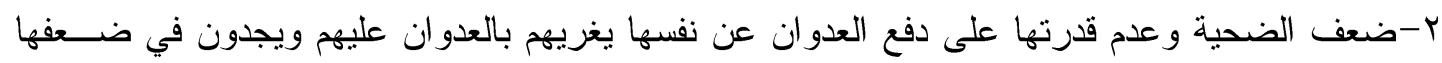

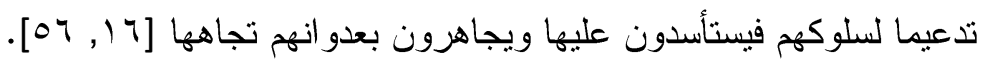




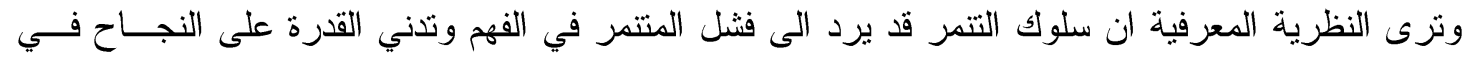
عمليات المعالجة الذهنية بالاضافة الى ظهور مظاهر معرفية لديه مثل : فنثل في معالجة الذهنية وفثل فــي فئي الانتباة و التركيز وفشل في النجاح و الانجاز وفشل في الانهماك في المهمة وفشل في استخدام قدرات الــتعلم

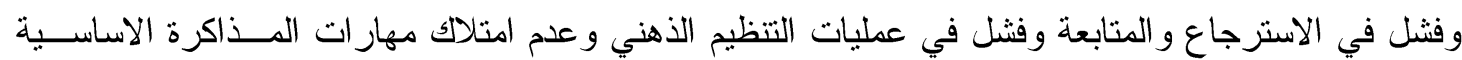

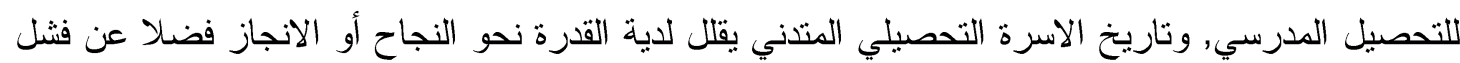

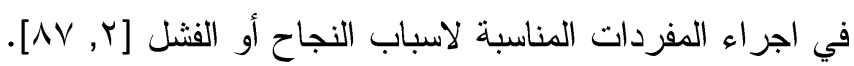

وتؤكد النظرية التاريخية الثقافية ان التنمر يحدث في سياقات اجتماعية ثقافية وان للغه دور الهاما في

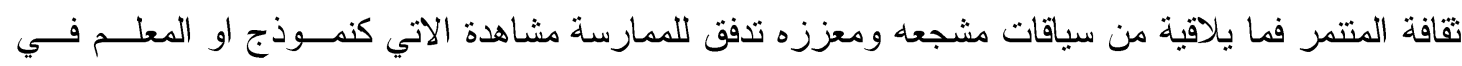

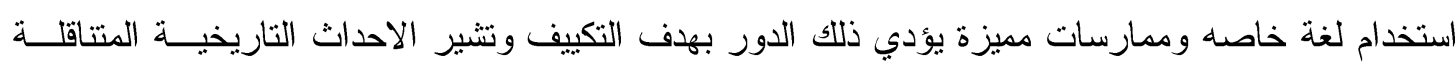

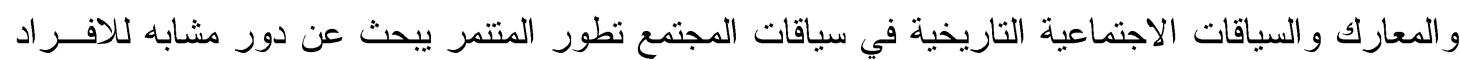

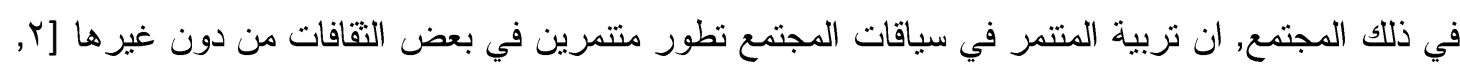

برى الباحثون ان مظاهر التنمر تتمثل في العـدوان اللفظـي (Verbal aggression) و التحــرش

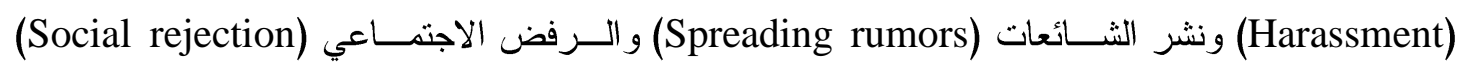

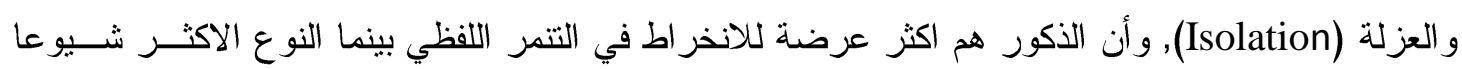
لاى الفتبات هو التتمر الاجتماعي (Cetin \& peker, 2011). وقسم سميث [17] التنمر الى اربعه انماط رئيسية وهي : ا-انفعالي: يتضمن هذا النمط (التهديد, الثتائم, السخرية من الضحية, الاســتبعاد مـن الاقــران, الاذلال, التحدث بقصص مزيفة ومخزية). ץ-جسدي: ويتضمن هذا النمط (الدفع, الضرب, الاصطدام بالضحية, سرقة الممتلكات الخاصــة و الادوات المدرسية). ب-جنسي: ويتضمن هذا النمط (التعليقات المخجلة على الاخرين, التحرش الجنسي بهم).

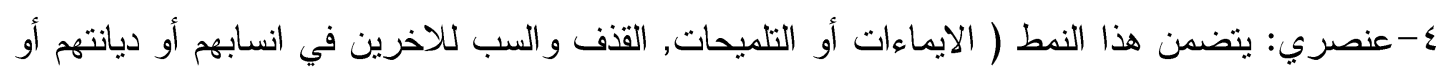

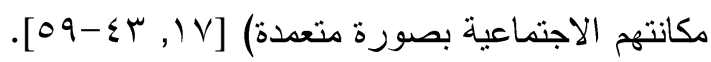
كما قسم عبد العظيم [1 1 ] سلوك النتمر الى: 1- سلوك مباشر: يقتضي مواجهه مباشرة بين كل من المتتمر و الضحية اذ يتضمن هذا الثكل مــن اثــكال

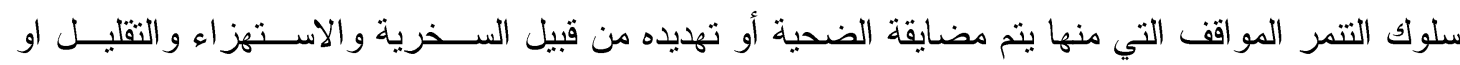

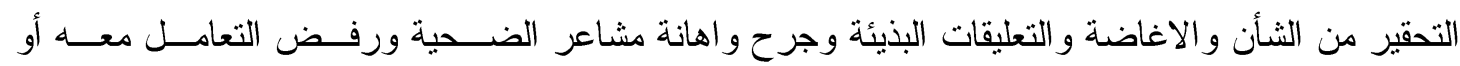
مخالطته وكذا التنابز بالالقاب البذيئة. 
r- سلوك غير مبانشر : يصعب ملاحظته ولكن يمكن استقراؤه أو استتناجه و الوقوف على اشكاله من (نشـر

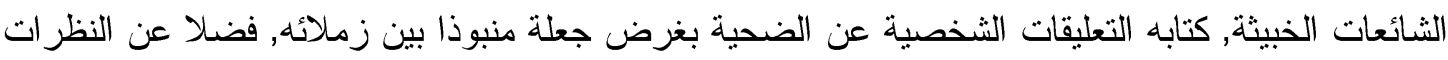

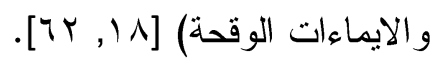

ثانيا: السلوك الاجتماعي (Social behavior) ان السلوك الانساني عموماً يعني" كل ما يصدر عن الإنسان من نشاط سواء أكان داخلياً في شــكل دو افع أو انفعالات ومهار ات وعمليات معرفية ودينامية، أو خارجياً يشمل السلوك الظاهر تجاه الآخرين". ويعد السلوك الاجتماعي للشخص نتاجاً لعملية تتفاعل فيها العو امل الحيوية التي تتبع من داخل الفرد

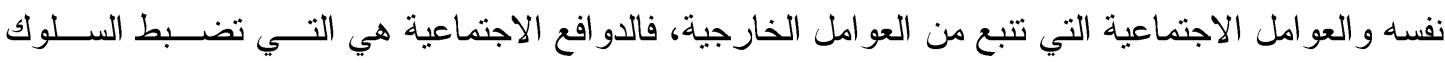

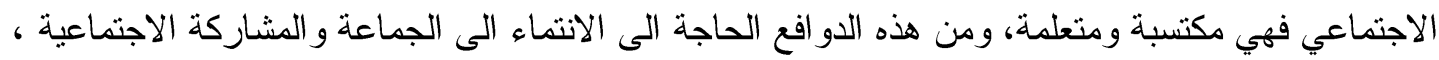
و الحاجة الى اثارة انتباه الاخرين و الحاجة الى الامن و والتقدير.

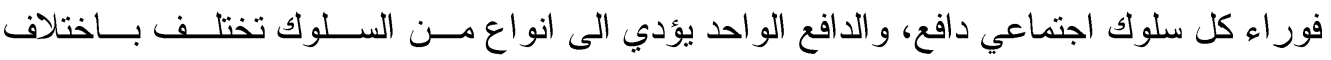
الافر اد، وقد يؤدي الى انو اع مختلفة من السلوك لدى الفرد نفسه تبعاً للموقف الخارجي. وقد يصدر الســــوك

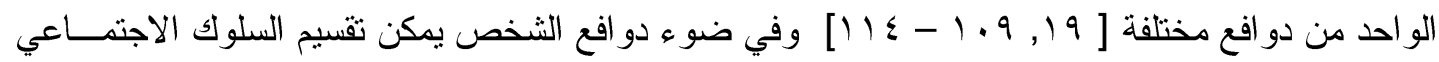

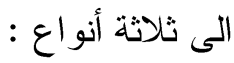

1- السلوك الاجتماعي الانفعالي : وتكون العاطفة مصدر هذا السلوك وهي تتتاقض مــع العقـل و الحكــــة

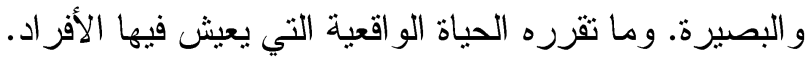

r. السلوك الاجتماعي التقليدي: وتكون العادات و التقاليد، و القيم، والمنل، و أخلاق المجتمع، مصدر هذا السلوك

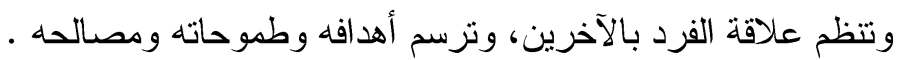

بـ. السلوك الاجتماعي العقلي: ويخرج هذا السلوك من منطقة الذات التي تعبر عن ماهيتــة، وحقيقــة العــالم

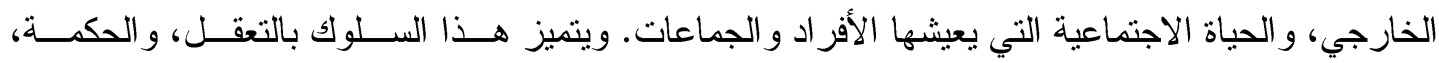

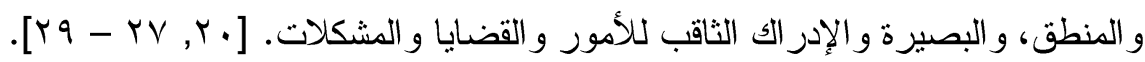
مستويات السلوك الاجتماعي: " يصدر السلوك الاجتماعي من الفرد، اما في علاقته بشخص آخر (العلاقات الثائية)، أو بمجموعة أصدقاء أو أحباء أو رفاق (الجماعات السيكولوجية غير الرسمية) أو اتجاه التجمعات الرسمية كعلاقات العمل،

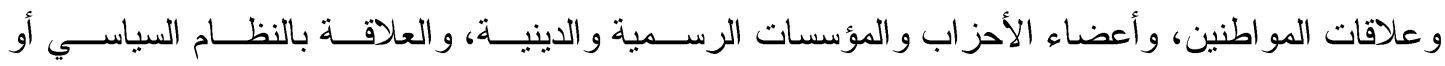

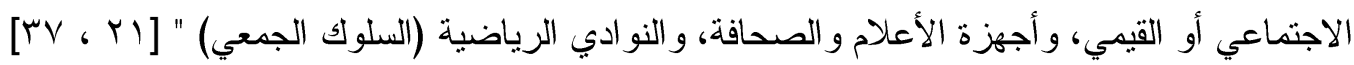
ويستعرض [1/r] ثلاثة مستو يات للسلوك الاجتماعي هي: 
Journal of University of Babylon, Humanities, Vol.(26), No(6): 2018

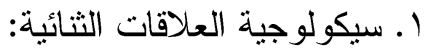

يصدر هذا السلوك من علاقة الثخص بشخص اخر ، وأهم هذه العلاقات هي العلاقة بــالأم - الأب الزوجة - زميل اخر •ويتأثر هذا السلوك بالعديد من العوامل التي تؤدي الى حدوث التجاذب وترسيخ العلاقة

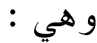

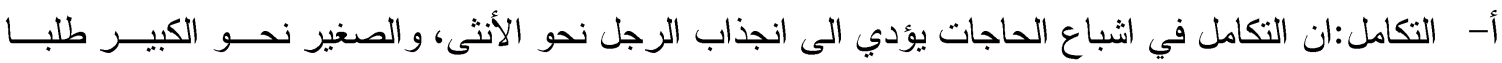

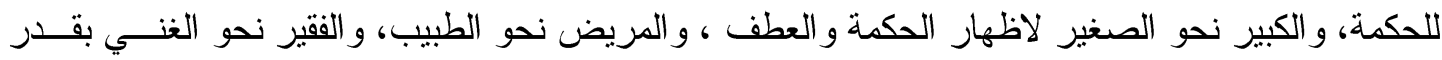
مايحتاج الغني إلى الفقير حتى يزداد شعوره بالكرم و العطاء .

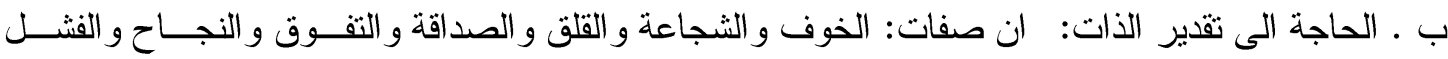
و الذكاء، لايمكن تقدير الذات عليها الا في وجود الاخرين . ل ج ـ التشابه: ان أغلب الناس يميلون الى من يثبهونهم، ففي أب تجمع نجد ان النساء يتقاربن فيما بينهن سويا

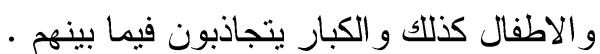
د ـ التقدير الضمني: ان الثخص اذا عرف أن هناك من يمتدحه ويعجب به، فان هذا يؤدي به الى الانجذاب نحو الشخص الاخر.

هـ. التقارب المكاني:ان التقارب المكاني يزيد من التجاذب بين الناس، فالجيران تزداد بينهم فرص الاتصال مما يتيح الفرصة للشعور بأوجه التشابه ونو احي التكامل.

و ـ المظهر الجسمي: فالثخص الحسن المظهر المعتتي بملابسه وهندامه يكون اكثر جاذبية من شـــص لا يبدو كذلك ـ فالمظهر الحسن يعكس نرتيباً في التقكير و المشاعر الحسنة. ز ـ الاعتقاد في عدالة العالم: يزيد هذا الاعتقاد في التجاذب مع الضحية، فالضحية اذا كانت بريئة مما يقـع

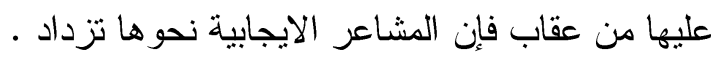

r. سيكولوجية الجماعات الصغيرة : يصدر هذا السلوك من علاقة الفرد بالجماعة التي تضم عدداً من الافراد

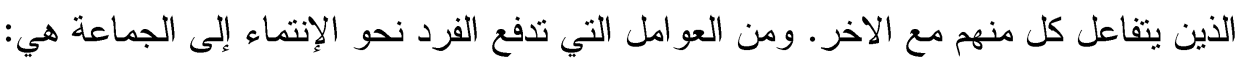
أ. تحقيق المنفعة الشخصية: فالفرد ينتمي إلى الجماعة لأجل إكتساب مكانة اجتماعية أو الحصول على أجر أكبر أو لتدعيم الثعور بالأمن.

ب. الرغبة في الإنتماء: يرغب الثخص في الانضمام إلى الجماعة لتحقيق رغبات نفسية كالثـــور بــالقوة،

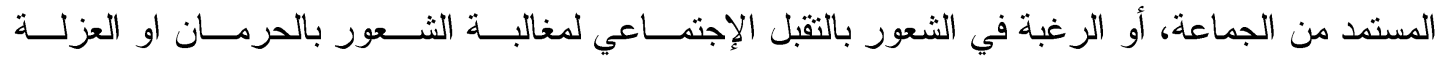
الإجتماعية، وقد يزداد طموحه ليتحول إلى الرغبة في الثعور بالقوة من قيادته لهذه الجماعة . ج • الإيثار: لا يستطيع الفرد تحقيق الرغبة في العطاء و إسداء النصح و المعونة إلى الإخرين إلا من الإنتماء

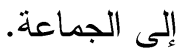
د ـ تشابه المعتقدات و الإتجاهات: يتوجه الفرد إلى الجماعات التي تتشابه معه في معتقداته و إتجاهاته. 
Journal of University of Babylon, Humanities, Vol.(26), No(6): 2018

هـ. عامل تماسك الجماعة: ان زيادة مشاعر التماسك و التآزر و الانتماء ومشاعر الوحدة و نحن في الجماعة

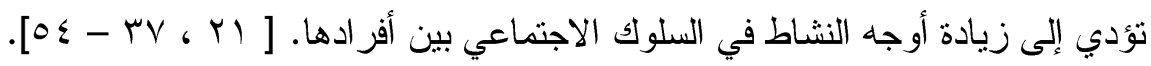

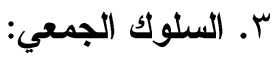

" سلوك الجمهرة أو الحشد الإجتماعي لعدد كبير من الأفراد يدخلون في علاقات اجتماعية متمبزة وروابط تتسم بالتفاعل لبلوغ أهداف معينة " ينتمي الثخص ويتفاعل مع جماعات وتجمعات ومؤسسـات رسـمية

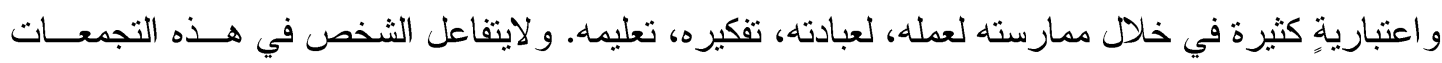

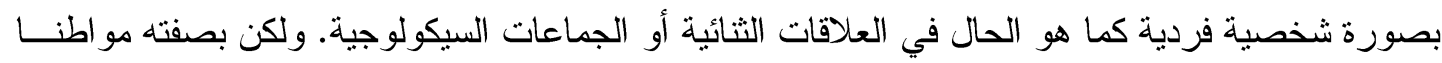

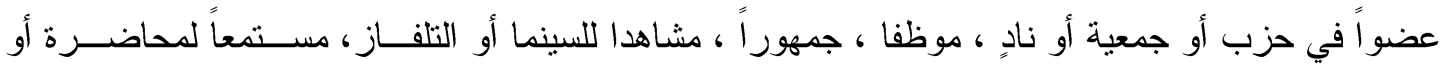

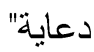
فالسلوك الجمعي هو الظو اهر غير المخططة التي تتشأ في هذه التجمعات كالاشاعات، و المظـــاهر ات، اتهات

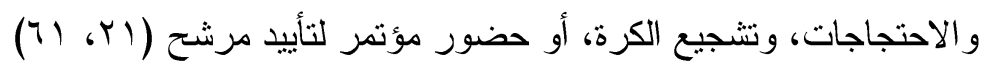
ويميز [Yr] نو عين من السلوك الجمعي هما : أ. السلوك الجمعي الانفعالي (سيكولوجية الحشود): يسود بين أعضاء الحشود، الانفعــال، وتبـــادل الخيــال،

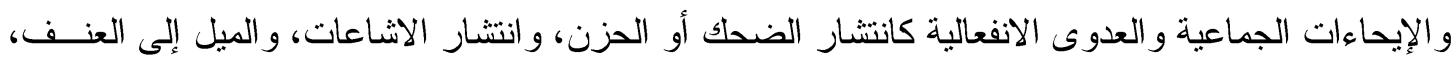

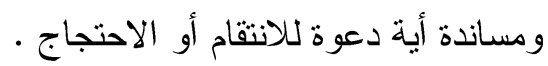
ب. السلوك الجمعي العقلاني (سيكولوجية الجماهير) : تتجمع مجموعة من الناس بصورة تلقائية حينما تكون

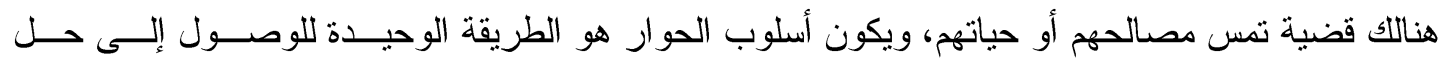

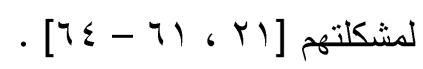

الاتجاهات النظرية في السلوك الاجتماعي (Theoretical Troends in Social Behavior) على الرغم من وجود نظريات متعددة في علم النفس حاولت تفسير السلوك الاجتماعي وفهمه، فلم تظهر أية

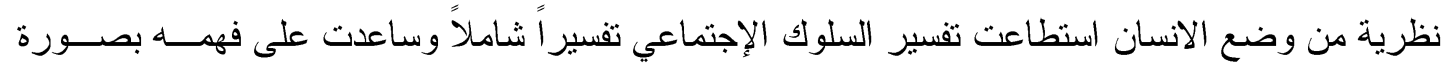

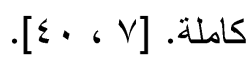
استتاداً إلى ما أثنار إليه دافيدوف [Yr] وشوان [Y] فانه يمكن تميز أربعة إتجاهات نظرية في تفسير

$$
\begin{aligned}
& \text { وفهم السلوك الإجتماعي هي : } \\
& \text { ا ـ الاتجاه التحليل النفسي. }
\end{aligned}
$$

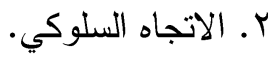

$$
\begin{aligned}
& \text { r. الاتجاه الجشتلتي الادر اكي المعرفي. } \\
& \text { ـ ـ الاتجاه الظاهر اتي الانساني [ب ، ، 0؛]. }
\end{aligned}
$$

أولاً. اتجاه التحليل النفسي: Psychoanalytic Trend 
Journal of University of Babylon, Humanities, Vol.(26), No(6): 2018

يؤكد هذا الاتجاه ان الطبيعة الفطرية للإنسان هي التي تتكل السلوك الإجتماعي لديه. [بr, ـ1 [1]. وتداول اصحاب هذا الاتجاه عددأ من اليات الدفاع التي تعدّ ذات اهمية في تفسبر انواع من السلوك

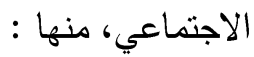

أ. الاسقاط Projection : الذي يعدّ المفسر الرئيس للاتجاهات التعصبية ضد الاقليات والاجانب ، فالعدوان أو الكر اهية التي يشعر بها الثخص نحو الأخرين يسقطها على هؤلاء الأخرين فيشعر انهم هم الذين يكرهونه

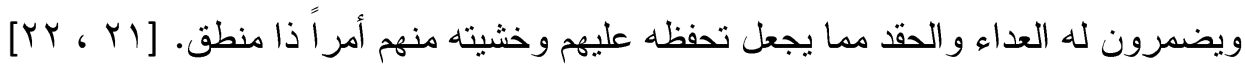

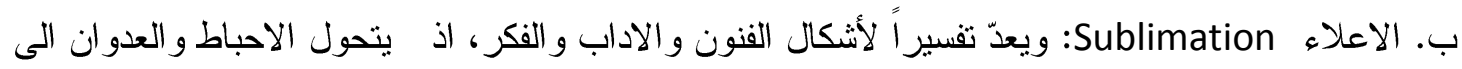

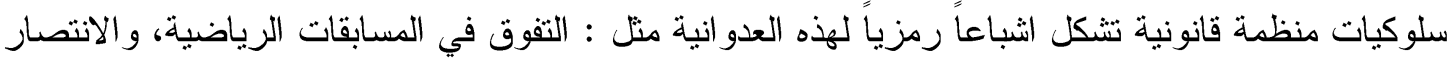
في مباريات الملاكمة و المصار عة، وضرب الارقام القياسية في عدد من الرياضيات. كذللك الفنون، و الاداب، و الفكر التي يكون التفوق والانتصار فيها هو التعبير القانوني المقبول عن تلك الرغبات الدفينة في العدوان. ومن جهة اخرى، يستطيع جمهور المشجعين ان يعبروا عن الوان التعصب بصورة مقبولة اجتماعياً اذ

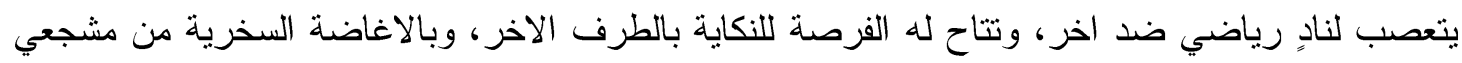

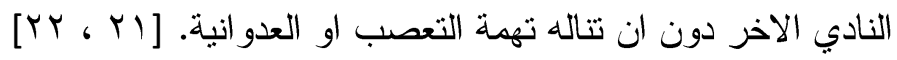

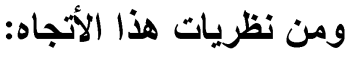

\section{Freuds psychoanalytic theory لظرية التحليل النفسي لفرويد:}

افترض فرويد ان الجهاز النفسي للفرد يتكون من ثلاثة انظمة هي: الهو، والانا، والانا الاعلى، و الاصل في هذا الجهاز هو الهو، أو الجزء اللاشعوري الذي يولد به الفرد . وهو بخصائصده اللاشعورية لا خلقي

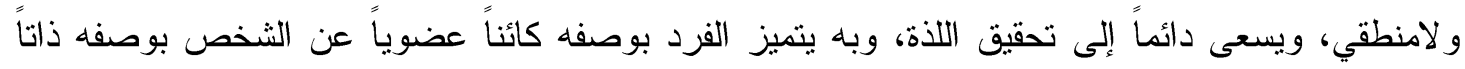

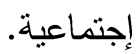

و عندما يتصل الهو بالمجتمع تبدأ عملية تكوين الأنا أو الصيرورة من الفردية الى الشخصية ـ ـوتعد

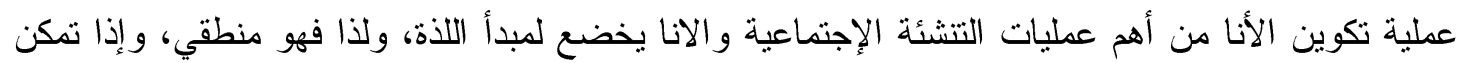
من تحقيق رغبات الهو فهو يحققها في إطار الو اقع الذي يفرضه المجتمع القائم بعاداته وتقاليده وقو انينه . ويشتق الفرد"الأنا الأعلى " سماعياً من أوامر الأب ونو اهيه ، وتدركها" الأنا ". أب ما يقوله الأب: امراً،

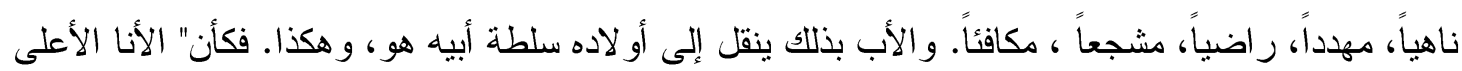

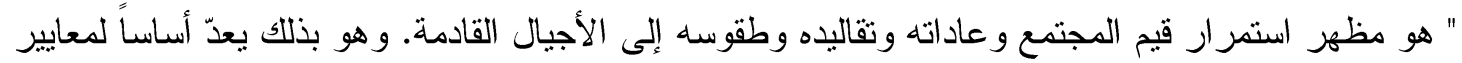
السلوك الإجتماعي.

وبذلك يكتسب الفرد سلوكه الاجتماعي من عادات وتقاليد ومعايير وقيم, عن طريق عمليتين رئيستين،

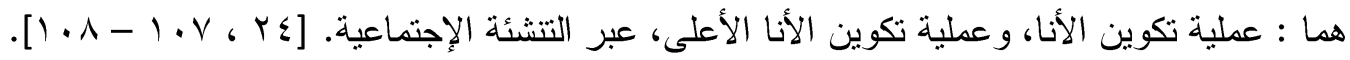
وفي الانسان السليم عقلياً تعمل هذه الأنظمة الثلاث سوية بتعاون، فتمكن الفرد من التفاعل المرضي

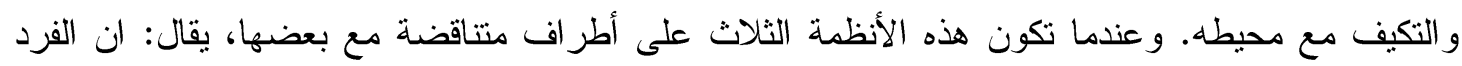


سيئ التكيف وسيئ الانسجام فهو غير راض عن نفسه، وغير قانع بالعالم وان كفاءته قد انخفضت [Yo،

ثانياً: الاتجاه السلوكي: Behaviorism Trend

يفسر هذا الاتجاه السلوك الانساني، ومنه السلوك الإجتماعي على وفق مبدأ " المثير - الاستجابة "،

ويهنم بالعملية التي يوفق بها الفرد بين تنظيمه لمجموعة استجاباته والتتوع الثديد للاستثارة ( داخلياً

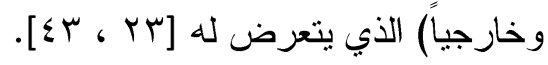

ومن نظريات هذا الاتجاه:

Theory Thorndik نظرية ثورندايك:

فسر السلوك الإجتماعي للفرد بانه: سلوك عشو ائي للوصول إلى هدف - مرتبط بحاجة عضوية - مأل

وحددت الإستجابة الناجحة بالصدفة هما يؤدي إلى الارتياح فتقوى العادة حتى تثبت.

ويرى ثورندايك ان جميع اثكال التعلم تعني تكوين ارتباطات بين المو اقف والاستجابات من ناحية

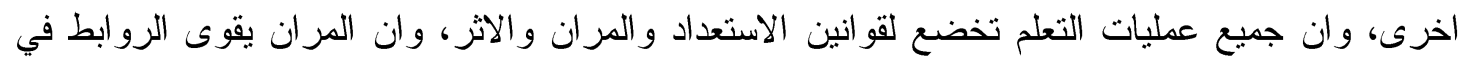

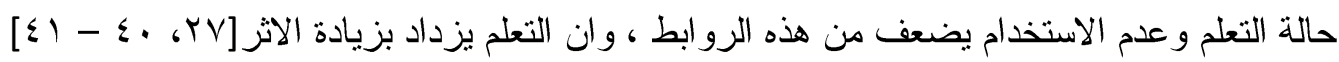

Skinner Theory نظرية سكنر (r)

ان اتجاه سكنر في تفسير السلوك الإجتماعي هو اتجاه ديناميكي، إذ يقوم على نظرية التعلم وهي

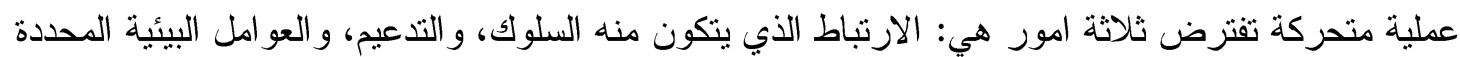

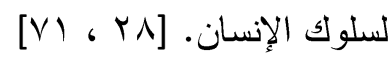

وميز سكنر بين نوعين من السلوك هما : السلوك الإستجابي الذي يتم اثتراطه بالمثير، و السلوك

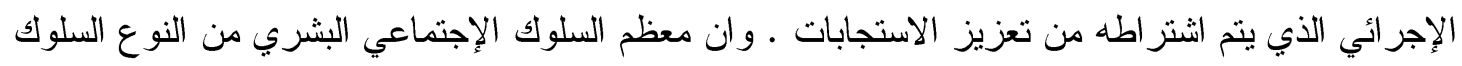

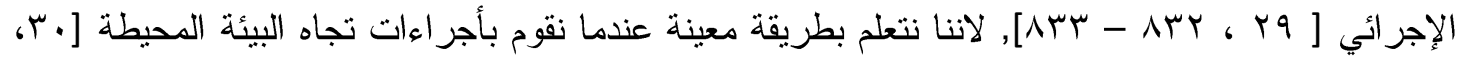

[IAV

ثالثاً:الاتجاه الجشتلتي الادراكي المعرفي Gestalt Cognitive Trend

يعد هذا الاتجاه السلوك البشري سلوكاً كلياً يحدث نتيجة لوجود الكائن الحي في مجال معين، بسبب في ذات الكائن مجموعة من الدو افع ، أو حالة من التوتز النفسي تجعل الذات تسلك في هذا المجال بطريقة معينة،

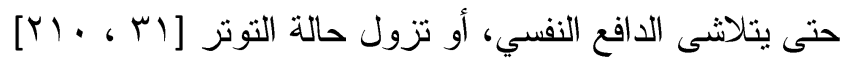
ومن نظريات هذا الاتجاه: - ات

\section{Gestalt's Theory (1) نظرية الجشتلت}

يعتقد اصحاب هذه النظرية ان السلوك الاجتماعي للفرد في جماعة ما يتحدد ويتخذ صفاته المميزة من التنظيم العام للجماعة، ويتشكل هذا السلوك نتيجة إدراك الفرد للوحدة العامة للنظام الاجتماعي أو عن لهن 
Journal of University of Babylon, Humanities, Vol.(26), No(6): 2018

طريق البصيرة ثم يتحدد بالتدريج بالانتقال من الكل الى الجزء، وان الإدرالك سابق لمختلف انماط السلوك

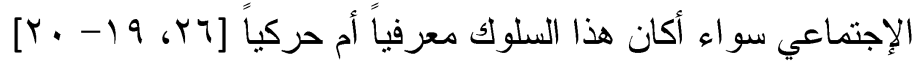

ويرون ان الفرد يتعلم السلوك الإجتماعي عن طريق تكوين اثار، عندما يكون الفرد في موقف إيجابي،

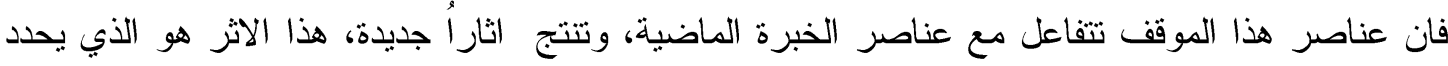

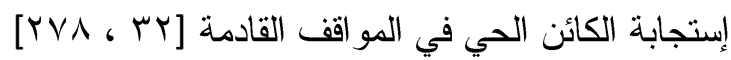

وبذلك فان كل ما نادوا به هو النظرة الكلية للسلوك الإجتماعي وأصروا على ان نقطة البداية المناسبة

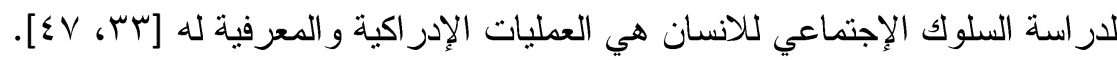

theory Lewins : نظرية المجال لكيرت ليفن

نظر ليفين للأحداث السلوكية في ضوء مكون (حيز الحياة) الذي يتضمن حاجات الفــرد وامكاناتــهـ

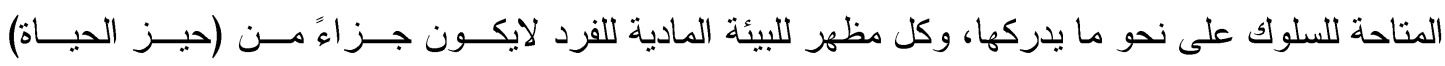
و لايستجيب له على نحو مباشر، فانه يمثل الغلاف الخارجي لحيز الحياة. ولفهم السلوك الإجتماعي للفرد في

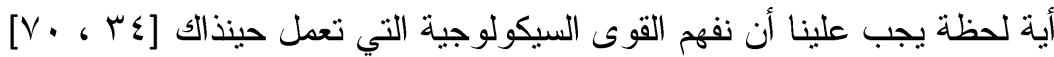
فسر ليفين السلوك الاجتماعي في ضوء العلاقات (الثخصية) الديناميكية في المحيط الاجتمـــاعي أو البيئــة

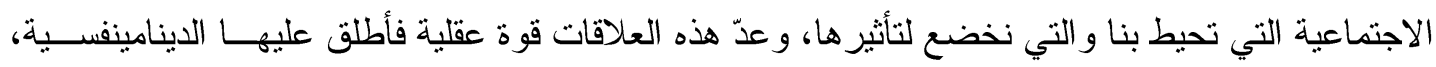

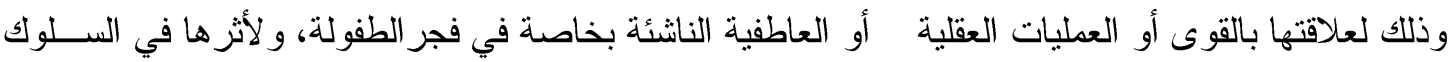

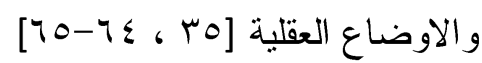

ويؤكد ليفين أن السلوك الإجتماعي للفرد يتحقق من اكتساب مميز ات الجماعة الحضارية ومثلهم ومبادئهر و هذه تؤدي إلى تغيير في التبعية للجماعة ، وبين ان مستوى الطموح لدى الفرد يعمل بوصفه دافعاً يزيد مـنـ

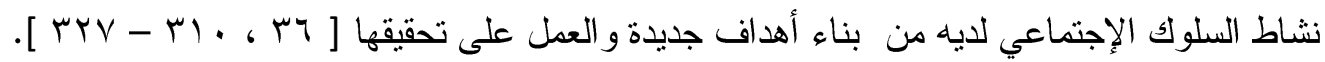

رابعاً : الاتجاه الظاهر اتي الانساني: Phenomenal- Humanistic Trend

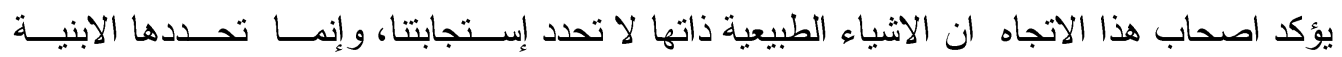

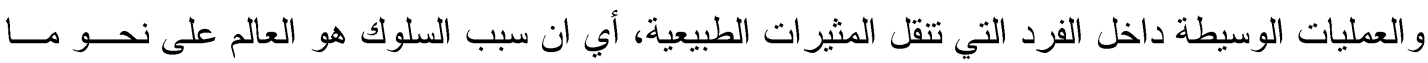

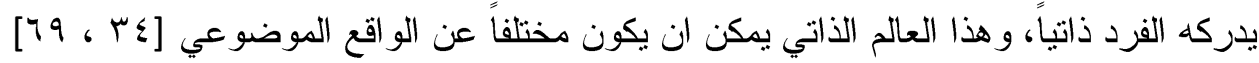

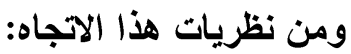

\section{نظرية كارل روجرز (Roger's Theory)}

ان تفسير روجرز للسلوك الإجتماعي ينبثق من الاتجاه الكلي في النظر إلى الظواهر النفسية وكذلك

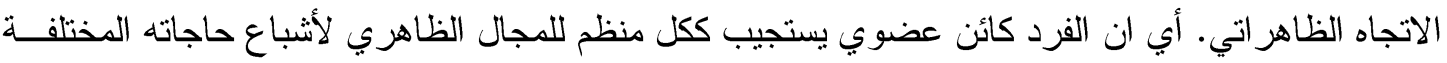

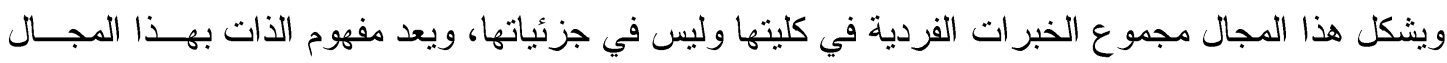

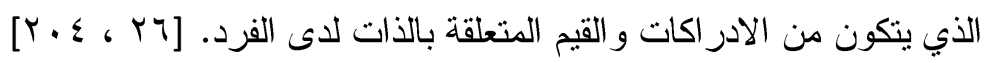


Journal of University of Babylon, Humanities, Vol.(26), No(6): 2018

ويرى روجرز أن الذات تتكون وتتحقق من النمو الايجابي، و أنها تتمثل في عناصر مثـلـل: صــفات الفــرد،

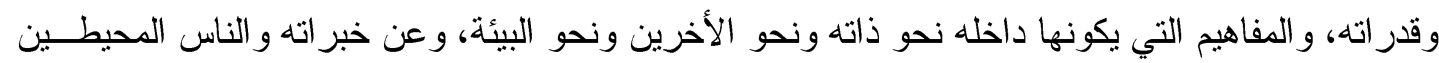

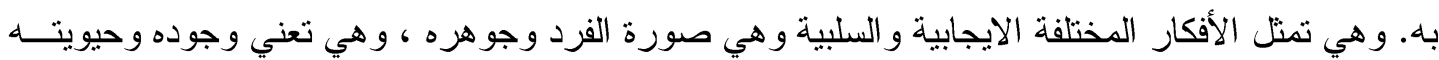
$[1,4, r v]$

و هذا المفهوم للذات هو الذي يحدد السلوك الإجتماعي للفرد ، وتعد هذه الذات الظاهرية حقيقة للفرد

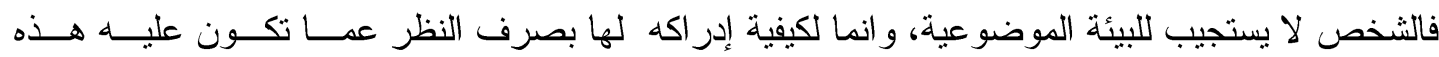

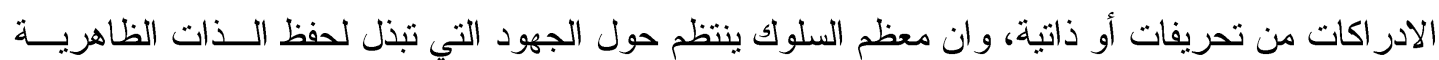

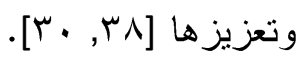

ويرى روجرز ان الميل إلى تحقيق الذات يتركز على انماء الذات من توجهها إلى الانشطة المتصــلة بالنمو و الارتقاء، ثم يرى ان دافع تحقيق الذات له وظيفة صائنة للفرد ومحققة لامكاناته وذللك في اطار البيئة

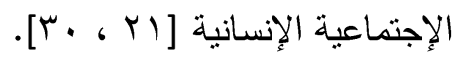
المحور الثاني/ الاراسات السابقة للتنمر والسلوك الاجتماعي أولا: دراسات سابقة تناولت التنمر:

(Connolly \& OMoore,2003) دراسة) العلاقات الاسرية والثخصية لاى الطلبة المتنمرين

استهدفت الدراسة الى التعرف في العلاقات الاسرية والثخصية لدى الطلبة المتتمرين وتكونت عينة

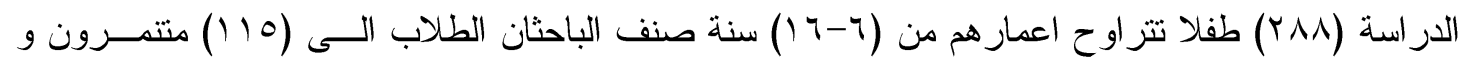
(T/1) غير متتمرون وقد استخدم اختبار ايزنك لقياس ابعاد الثخصية واستخدم اختبار العلاقــات الاســرية

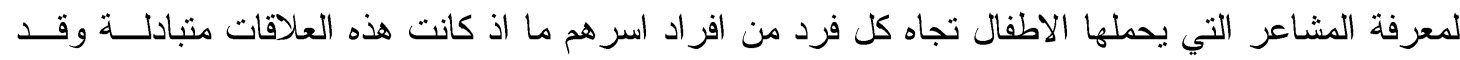
اظهرت نتائج الدر اسة الى ان الاطفال المتنمرين يعانون من حرمان عاطفي في حين اظهر الاطفــال غيــر

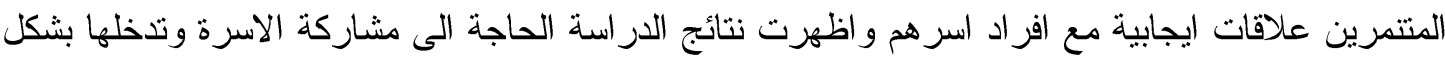

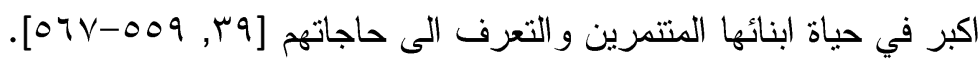
تانيا: دراسات سابقة تناولت السلوك الاجتماعي: 1- إسة (شوان, 1991)

\section{بناء مقياس مقنن للسلوك الاجتماعي لاى طلبة الجامعه في العراق}

اجريت الدر اسة في العر اق، وهدفت إلى بناء مقياس مقنن للسلوك الإجتماعي عند طلبة الجامعة وقياســه

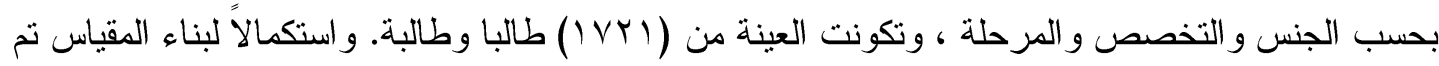

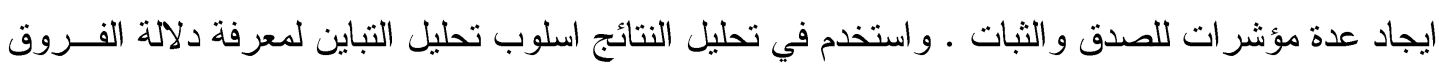

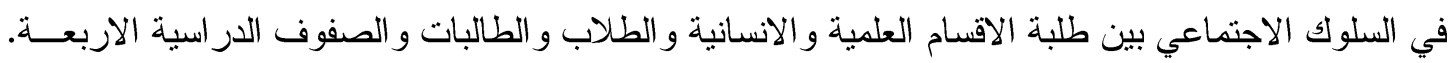
وبعد التطبيق وتصحيح الاجابات نم التوصل إلى النتائج الاتية: •ان طلبة الجامعة في العراق يتمتعون بالسلوك الإجتماعي المرغوب فيه. 


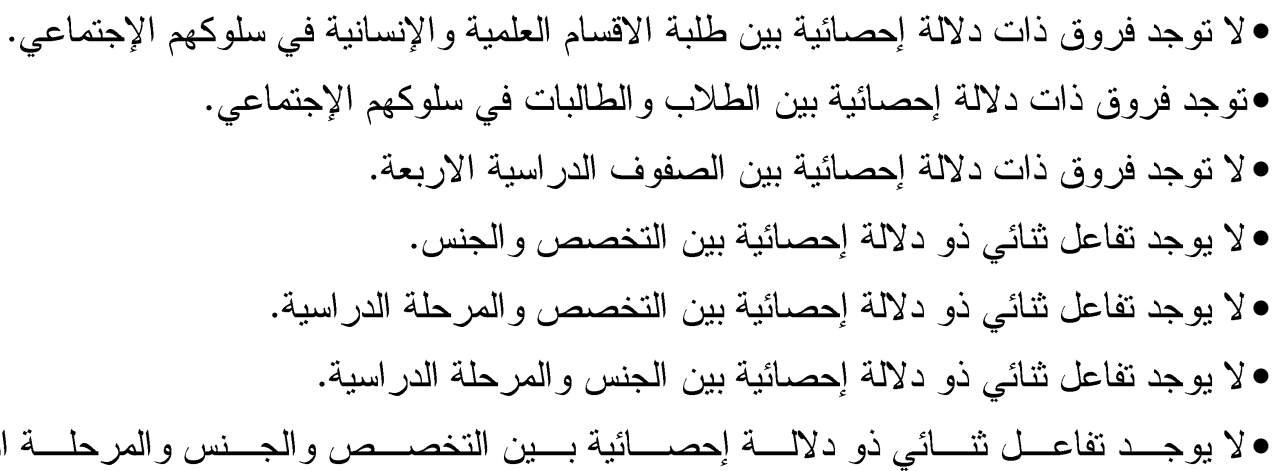

( $v)$

مناقشة الار اسات السابقة:

1-الاهداف: ذهبت مجموعة من الدر اسات الى بحث العلاقات الاسرية و الثخصية لدى الطلبة المتنمرين[9؟] وتتاولت در اسة [V] بناء مقياس مقنن للسلوك الاجتماعي عند طلبة الجامعه وقياسة بحسب الجنس و التخصص

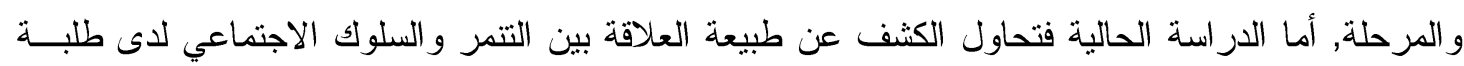
المرحلة المتوسطة.

r-طبيعة العينة: تبين من استعر اض الدراسات السابقة انها اجريت على عينات من المرحلة المتوسطة وطلبة المرحلة الجامعية, وعينه البحث الحالي هم من طلبة المرحلة المنوسطة.

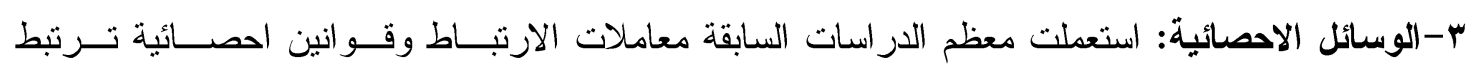

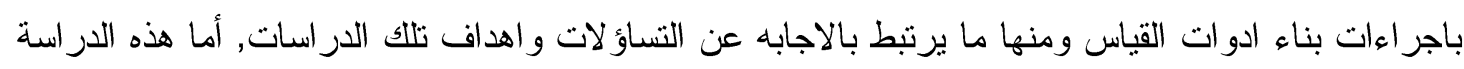
فقد استعملت اختبار (T-test) لعينة واحدة ولعينتين مستقلتين ومعامل ارتباط بيرسون.

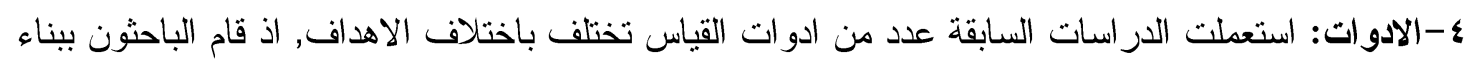

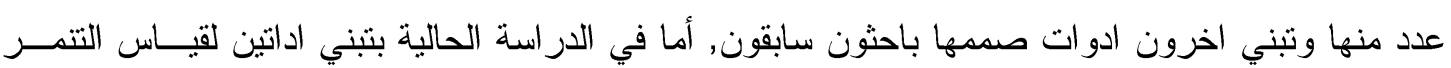
و السلوك الاجتماعي. جوانب الافادة من الار اسات السابقة: - - افاد الباحث في اختيار طبيعة المجتمع وحجم عينته.

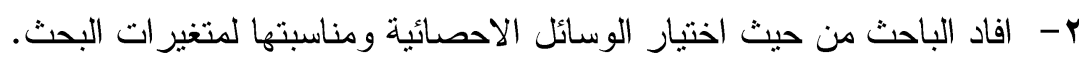
r- الاطلاع على المصادر ذات العلاقة بموضوع البحث. ع - الافادة من النتائج التي توصلت اليها الدراسات السابقة ومناقتتها بنتائج الدراسة الحالية. ه - الافادة من منهجية البحث و المقاييس التي استعملت وملائمتها لعينة الدراسة. 
Journal of University of Babylon, Humanities, Vol.(26), No(6): 2018

\section{الفصل الثالث/ منهجية البحث واجراءتهـ.}

يتضمن هذا الفصل عرضـا لمنهج البحث و اجر اءاته لتحقيق اهدافه. وشملت تلك الاجر اءات تحديد مجتمـع

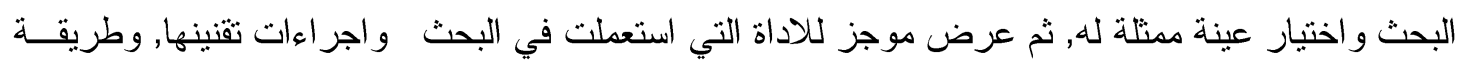

تطبيقها

أولا: منهج البحث:

استعمل الباحث المنهج الوصفي الارتباطي لاجر اء هذا البحث لكونه المنهج المناسب لطبيعة البحث الذي يتطلب جمع البيانات حول عدد من المتغيرات التي يتتاولها, ومعرفة حجم ونوع العلاقات لبين البيانـات [ • ؛.

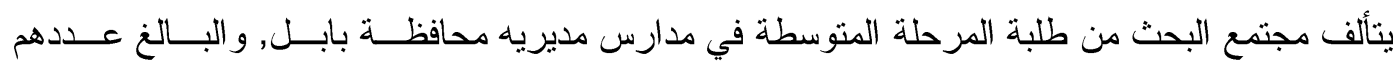

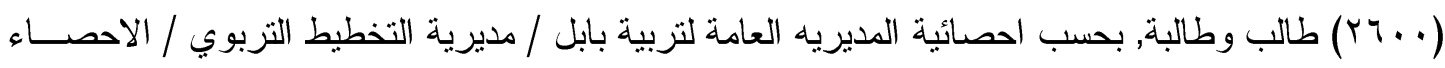

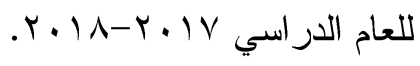

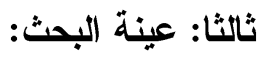

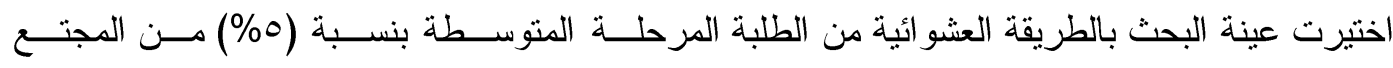

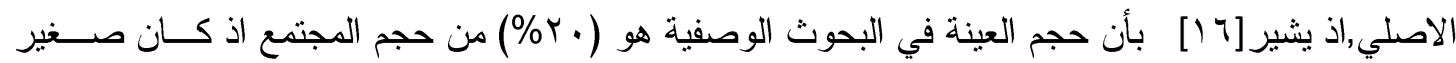

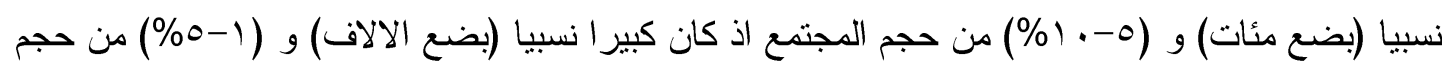
المجتمع اذ كان كبير ا جدا (عشرات ات الالاف)

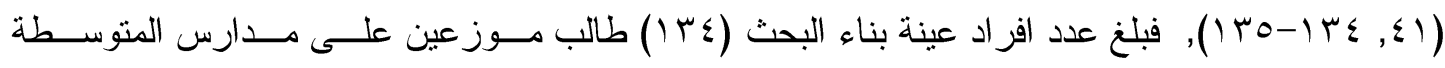

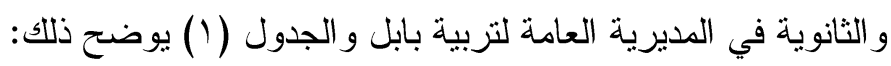

جدول(1) أفراد عينة البحث الموزعين في المدارس

\begin{tabular}{|c|c|c|}
\hline ذكور & اسم المدرسة & ت \\
\hline 11 & متوسطة ابن نما للبنين & 1 \\
\hline$r r$ & ثانوية الاستور للبنين & r \\
\hline 17 & متوسطة فرات الخير & $r$ \\
\hline ro & متوسطة دمثت للبنين & $\varepsilon$ \\
\hline$r \varepsilon$ & ثانوية الجزائر للبنين & ○ \\
\hline 11 & متوسطة دعبل الخزاعي للبنين & 4 \\
\hline Ir & 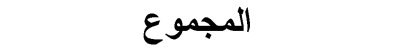 & \\
\hline
\end{tabular}




\section{رابعا: اداتا البحث (Research Scales):}

$$
\text { قام الباحث بالخطو ات التالية لاعداد مقياس التتمر : }
$$

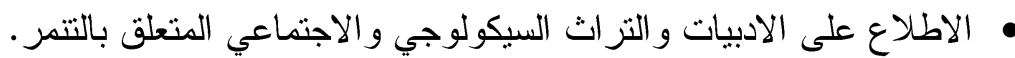

• الاطلاع على بعض المقاييس في مجال التنمر التي اتيح للباحث الاطلاع عليها, و الاستفادة منها من حيـث توزيع العبار ات على محاور المقياس المختلفة, واختيار الفقرات التي تتناسب مع عينة البحث ومنها: 1-مقياس التنمر عند الاطفال اعداد اسامة الصوفي وفاطمة هاثش (Y ( • Y).

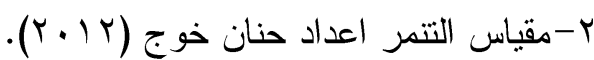

( SELF Research Centre, University of Western ب-مركز الابحاث سيلف, جامعه غرب سـدني Sydney).

وبذلك اصبح عدد فقرات المقياس (·r) فقرة موزعه على ثلاث مجــالات: هـي التنمــر اللفظـي, التتــر الاجتماعي, التنمر الجسدي على التوالي.

[V] أما مقياس السلوك الاجتماعي تبنى الباحث مقياس صياغة فقرات المقياسين: ان اي مقياس يتم تصميمه يتكون في نهاية الامر من مجموعه من الفقـر ات, ويتحدد ترتيب الفقرات في المقياس على وفق صعوبتها, بحيث تصبح من حيث شكلها وتكوينهــا وصــعوبتها

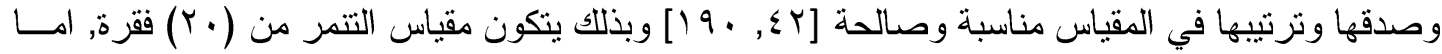
مقياس السلوك الاجتماعي فيتكون من (Tه) فقرة.

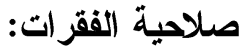

عرض المقياسين بصورتهما الاولية على مجموعه من المحكمين من ذوي الاختصاص وطلب منهم الحكم على صلاحية الفقرات في قياس التنمر وقياس السلوك الاجتماعي, وابداء ملحوظاتهم و ارائهم في مايخص صياغة الفقرات و انتماءها للمقياس, وتعديل بعض الفقرات او اضافتها, وقد اعتمد الباحث على مو افقة (•^\%\%) من الخبر اء المحكمين محكا لصلاحية الفقرات ملحق (؟), وبعد تحليل اجابات المحكمين تبين اتفاقه جميعا على صلاحية الفقزات كافة وبنسبة (. (1\%), ولم تحذف اية فقرة ولم يجر اي تعديل على

تعد تعليمات المقياس بمثابة الدليل الذي يسترشد به المستجيب, لذا روعي في اعداد تعليمات المقياسـين ان

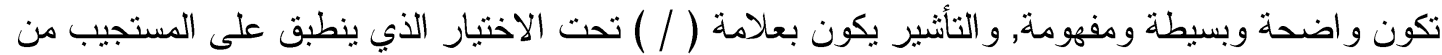

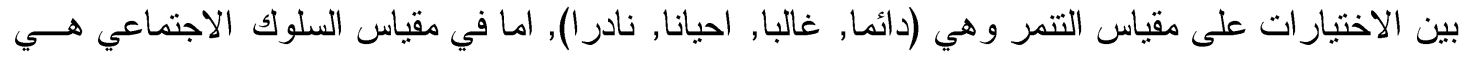
بدائل (السلوك الاجتماعي الذي تقيسه الفقرة باعلى درجة, السلوك الاجتماعي الكقاس بدرجة اقـلـل, لايقـيس السلوك الاجتماعي المرغوب فيه), وقد اكدت سرية الاجابة, ولم يطلب من المستجيب ذكر اسمة ووضح لــهـ ان الاجابة لاغر اض البحث العلمي. 
يقصد به الاستجابة لكل مستجيب على كل فقرة من فقرات المقياس التتمر , واستخر اج الدرجة الكلية عن طريق جمع درجات الاستجابة على المقياس, ولتحقيق هذا الغرض اعتمد الباحث طريقة (ليكرت) وذللك

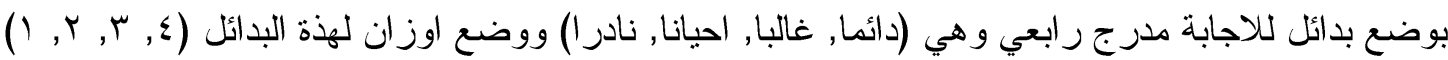

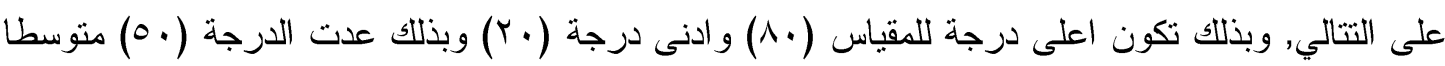

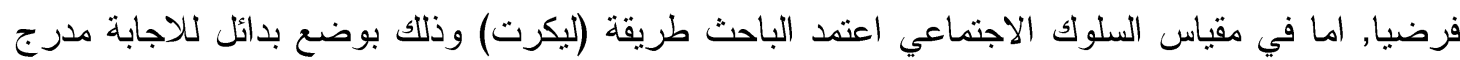

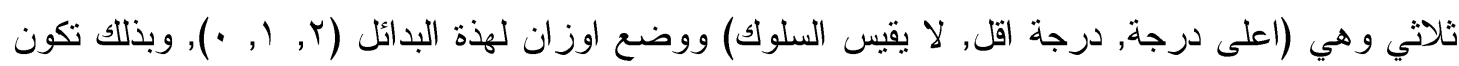

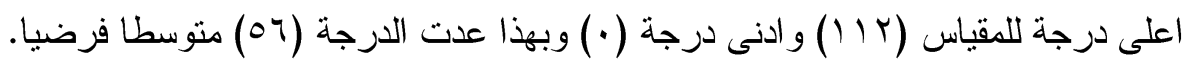
عينة التطبيق الاستطلاعي:

من اجل التعرف على وضوح تعليمات المقياس ومو افقة فقر اته و الكثف عن المو اقــف الغامضـــة و غبر الو اضحة وكذلك حساب معدل الوقت المستغرق في الاجابة عن جميع فقرات المقياس, طبق المقياسـين

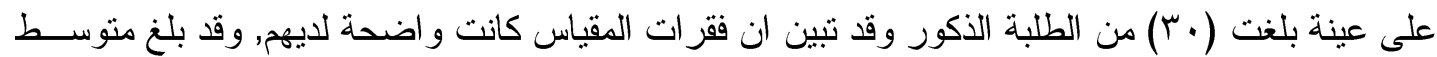
الوقت المستغرق للاجابة على المقياسين (• ب) دقيقة. التحليل الاحصائي لفقرات مقياس التنمر ومقياس السلوك الاجتماعي:

يهدف التحليل الاحصائي لفقرات المقياس, اختيار الفقرات التي تقيس سمة معينة قياسا دقيقا بوساطة

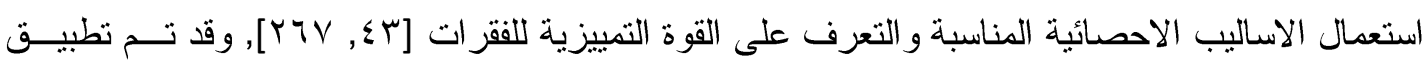

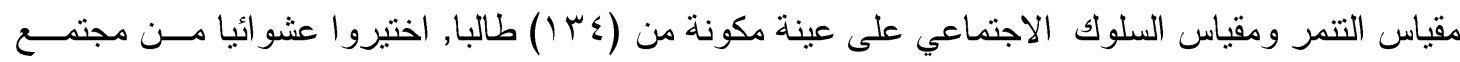
البحث ومن غير عينة البحث.

1- اسلوب المجموعتين المتطرفتين (Contrasted Group Method): لغرض اجر اء التحليل بهذا الاسلوب اتبع الباحث الخطوات الاتية:

1- تطبيق فقرات مقياس التتمر ومقياس السلوك الاجتماعي على عينة التحليل الاحصائي البالغ عددها (ع ب ا) طالبا من طلبة في المدراس المتوسطة والثانوية في المديرية العامة لتربية بابل. r- تصحيح اجابات الطلبة لايجاد الدرجة الكلية لاستجابة كل طالب عن فقرات المقياسين. ب- ترتيب درجات الطلبة ترتيبا تتازليا لاختيار (rr\%) من الاستمارات التي حصلت على اعلى الدرجات

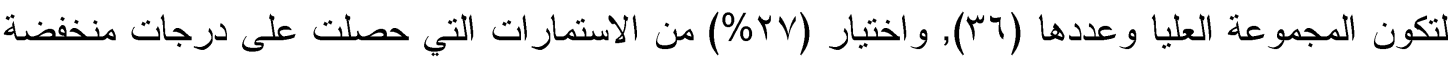
لتكون المجموعة الدنيا و عددها (Tب).

ع - استخر اج معامل التمييز باستعمال اختبار (T-test) لعينتين مستقلتين لاختبار الفرق بين المجموعتين

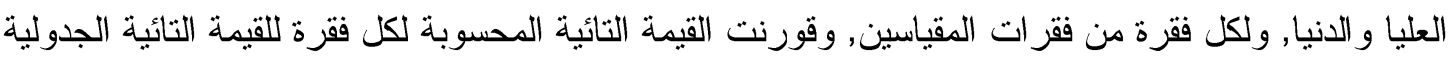

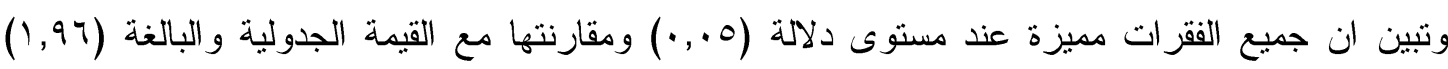

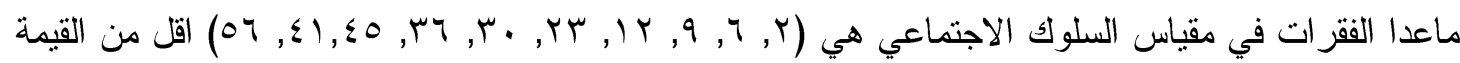

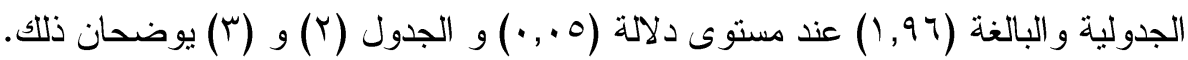


مجلة جامهة بابل، الهلوم الانسانية، المجلد רج، العدد T: MIاיP Journal of University of Babylon, Humanities, Vol.(26), No(6): 2018

جدول (r) القوة التمييزية لفقرات مقياس التنمر باستعمال اسلوب المجموعتين المتطرفتين

\begin{tabular}{|c|c|c|c|c|c|}
\hline \multirow{2}{*}{ القيمة التائية } & \multicolumn{2}{|c|}{ المجموعة الدنيا } & \multicolumn{2}{|c|}{ المجموعة العليا } & \multirow[b]{2}{*}{$ت$} \\
\hline & الاتحر اف & الحسابي & الاتحر اف & الحسابي & \\
\hline 7,101 &., $70 \mathrm{~V}$ & $r, r r$ & $\cdot, \varepsilon \leqslant V$ & $r, \vee \wedge$ & 1 \\
\hline $7,1 \wedge \wedge$ & 1, & $r, q 0$ &., $0 \vee 7$ & $r, v v$ & r \\
\hline ד, ד . & $\cdot, \wedge 9 \leq$ & $r, \varepsilon r$ & $\cdot, v \leq 9$ & r.r. & $r$ \\
\hline$\Lambda, r \cdot \vee$ & $\cdot, q \vee r$ & 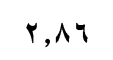 & $\cdot, r \wedge$. & $r, \wedge r$ & $\varepsilon$ \\
\hline$v, 11 r$ & $1,0 \leq \varepsilon$ & r,q. & $\cdot, \leqslant \diamond \uparrow$ & $\Gamma, \Lambda$. & ○ \\
\hline V,^५. & $\cdot, 9 \leq r$ & r, vo &., 017 & $r, 79$ & 9 \\
\hline 0,097 & $1, .07$ & $r, q \varepsilon$ & .707 & $r, v r$ & v \\
\hline $7,9.7$ & $1,+\leq 4$ & r,qu & $\cdot, \leqslant \diamond q$ & $\Psi, \Lambda$. & $\wedge$ \\
\hline 9,110 & $\cdot, \wedge 97$ & $r, 01$ &., $07 \mathrm{~V}$ & $\Gamma, \diamond \wedge$ & 9 \\
\hline 0,7 イ & $1, .1$. & $r, v \varepsilon$ & $\cdot, \vee ५$. & $r, O r$ & 1. \\
\hline$\Lambda, r \leq r$ & $\cdot, 9 \vee 7$ & Y,^० & $\cdot, r q 1$ & $r, \wedge !$ & 11 \\
\hline$\varepsilon, 10 r$ &., $9 \mu v$ & $r, 10$ & . & ץ, ^ & ir \\
\hline$\Lambda, \varepsilon \cdot \varepsilon$ &., 909 & 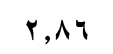 & $\cdot, r \wedge$. & $r, \wedge r$ & ir \\
\hline$V, 01 Y$ & $1, \cdot r$ & r,Tr &., $0 \wedge r$ & r,Tr & $1 \varepsilon$ \\
\hline$\varepsilon, Y \backslash V$ & $\cdot, \wedge \backslash \wedge$ & $r, i v$ & $\cdot, \diamond \vee V$ & $r, T \leq$ & 10 \\
\hline$q, \varepsilon r r$ & $\cdot, \wedge 97$ & $r, \varepsilon V$ &., $07 \mathrm{~V}$ & $\Gamma, \diamond \wedge$ & 17 \\
\hline $0,1 Y \wedge$ & •,^r. & r., & • & $r, \wedge q$ & iv \\
\hline$v, r \cdot v$ & $1, .1 r$ & $r, \vee \wedge$ & $\cdot, \leqslant 91$ & $r, 79$ & 11 \\
\hline $7, \varepsilon \cdot 7$ &., 900 & $r, q q$ & I, , & $r, v v$ & 19 \\
\hline$r, 1.9$ & $\cdot, 9 \wedge 9$ & $r, 10$ & $\cdot, V \cdot q$ & $r, O V$ & $r$. \\
\hline
\end{tabular}


مجلة جامهة بابل، الهلوم الانسانية، المجلد רج، العدد T: MIاיP Journal of University of Babylon, Humanities, Vol.(26), No(6): 2018

جدول (ץ) القوة التمييزية لفقرات السلوك الاجتماعي باستعمال المجموعتين المتطرفتين

\begin{tabular}{|c|c|c|c|c|c|}
\hline \multirow{2}{*}{ قيمة التائية } & \multicolumn{2}{|c|}{ المجموعة الانيا } & \multicolumn{2}{|c|}{ المجموعة العليا } & \multirow[b]{2}{*}{$ت$} \\
\hline & الإتحر اف & الوسطي & الإنحر اف & الوسطا & \\
\hline$r, 19 r$ &., $00 r$ & $r, .9$ & $\cdot, \diamond \wedge$ & $r, r v$ & 1 \\
\hline $1,0 \wedge r$ & $\cdot, 741$ & $1, \wedge \varepsilon$ & $\cdot, 7 r q$ & $1,7 \wedge$ & r \\
\hline$\varepsilon, 7.7$ & $\cdot, V \leq r$ & $r, \ldots$ & $\cdot, 70 \leqslant$ & $r, 01$ & $r$ \\
\hline$v, r \cdot r$ & $\cdot, V M r$ & $1, \wedge$ & $\cdot, 7 \cdot 7$ & $r, \tau$. & $\varepsilon$ \\
\hline$r, \wedge r q$ & $\cdot, \Lambda \cdot r$ & $r, \cdot v$ & $\cdot, v \cdot q$ & r,Or & - \\
\hline $1, \leqslant 1$. & $\cdot, \vee r \wedge$ & 1,94 & $\cdot, v 11$ & $r, . q$ & 7 \\
\hline$\varepsilon, 11 r$ &., $71 V$ & 1,00 & 1,.4r & $r, \varepsilon r$ & v \\
\hline $0, q^{\circ}$. & $\cdot, \uparrow \wedge$ & $1,7 \varepsilon$ &., $7 \vee q$ & $r, r$. & $\wedge$ \\
\hline 1,190 & $\cdot, v \cdot 1$ & r, & $\cdot, 711$ & $r, \varepsilon r$ & 9 \\
\hline O, rY. & $\cdot, 7 \wedge 9$ & $r, r V$ & •, $\{\leqslant \leqslant$ & r, Vo & 1. \\
\hline A, & $\cdot, V \cdot \varepsilon$ & $r, r r$ & $\cdot, 701$ & $Y, O V$ & 11 \\
\hline צr & , VRr & $1, \wedge$ & $\cdot, \vee \vee 0$ & $1, \wedge \varepsilon$ & ir \\
\hline$\varepsilon, r, q$ & .,Orr & T, T & • & r,qr & IT \\
\hline $0,7 \leq$. & $\bullet, \vee \bullet$ & 1,99 & $\cdot, 7 \cdot 1$ & r,०q & $1 \varepsilon$ \\
\hline$\varepsilon, \cdot r q$ & ס ס ד, י & 1,9 . & $\cdot, T H$ & $r, r$. & 10 \\
\hline$\varepsilon, V Y r$ & $\cdot, v \cdot v$ & $1,9 \wedge$ & $\cdot, 0 \leqslant \wedge$ & $r, \varepsilon \varepsilon$ & 17 \\
\hline$r, 0.1$ & •, & Y, Is & ס • , • & $r, \varepsilon q$ & iv \\
\hline$\varepsilon, \varepsilon \varepsilon$. & $\cdot, 7 r V$ & $r, r_{1}$ & .,ork & $r, r r$ & 11 \\
\hline r,qvi & $\cdot, V Y Y$ & $r, 10$ & $\cdot, \circ \vee$ & $r, 0 Y$ & 19 \\
\hline r,भ V & $\cdot, \vee \wedge \bullet$ & $r, r_{1}$ & ., orq & $r, 7 q$ & $r$. \\
\hline$r, q \leq 0$ & $1, \cdots 1$ & $r, \bullet \wedge$ & , , $\wedge r$. & $r, r \varepsilon$ & ri \\
\hline$\varepsilon, r \leq q$ & גד & $r, \varepsilon r$ & $\cdot, \leqslant \circ q$ & $r, \Lambda$. & $r r$ \\
\hline 1, Vrr & $\cdot, \vee \backslash \varepsilon$ & $r, r$. & $\cdot, 7 \leq \varepsilon$ & $r, r \wedge$ & r \\
\hline$r, 999$ & $\cdot, v+1$ & r, $\varepsilon$. &,,$\infty$, & $r, \vee \wedge$ & $r \varepsilon$ \\
\hline r,ONY & $\cdot, \vee \vee q$ & $r, r \wedge$ & $\cdot, 7 \vee \cdot$ & r,OV & ro \\
\hline $0, \ldots r$ & $\cdot, \vee \vee q$. & $r, \cdot r$ & $\cdot, 7 \leqslant \Lambda$ & r,०q & r \\
\hline
\end{tabular}


مجلة جامهة بابل، الهلوم الانسانية، المجلد רج، العدد T: MIاיP Journal of University of Babylon, Humanities, Vol.(26), No(6): 2018

\begin{tabular}{|c|c|c|c|c|c|}
\hline $4, \vee 01$ & $\cdot, v \otimes \wedge$ & 1,91 & , Or & r,TV & $r V$ \\
\hline$v, \cdot \wedge r$ & , , Vr. & $1, \wedge 4$ & $\cdot, 7 \cdot 7$ & $r, r$. & $r \wedge$ \\
\hline$\vee, \diamond \vee q$ & $\cdot, V \leqslant V$ & $1,9 \leq$ & $\cdot, \leqslant 91$ & $r, 79$ & $r q$ \\
\hline $1,79$. & • & $r, 10$ & $\cdot, 700$ & r, & $r$. \\
\hline $0, \ldots \varepsilon$ & . , $7 \leq 1$ & $r, r v$ & $\cdot, \leqslant \vee V$ & $r, \Lambda I$ & ו \\
\hline$\checkmark, \wedge \vee \vee$ & , $\vee ৭$ & $1,9 \varepsilon$ & .,Or & r, TV & rr \\
\hline$\Lambda,|M|$ & . & 1,97 & ד & $r, v$. & $r r$ \\
\hline$V, T \leqslant r$ & $\cdot, v \leq q$ & $r, \cdot \varepsilon$ & $\cdot, \leqslant \leqslant V$ & $r, \vee \wedge$ & $r \varepsilon$ \\
\hline$r, r \wedge r$ & $\cdot, V \leq 0$ & 1,91 &., 079 & $r, O V$ & ro \\
\hline $1, \wedge \leq \varepsilon$ & $\cdot, \vee \vee q 9$ & $r, \cdot \varepsilon$ &., 799 & r, ro & T \\
\hline$r, \leqslant q \wedge$ & $1, \cdot \wedge r$ & $r, \vee q$ & $\cdot, v \cdot \Lambda$ & $r, \diamond \wedge$ & $r v$ \\
\hline 0,701 & $\cdot, V \leq 1$ & $r, \cdot r$ & $\cdot, O \wedge r$ & $r, T r$ & rs \\
\hline 7,070 & $\cdot, V \wedge r$ & $r, r$ & \& & $r, q 1$ & rq \\
\hline $0, \wedge>0$ & $\cdot, V Y V$ & r, & V & $r, \wedge \wedge$ & $\varepsilon$. \\
\hline $1, r q$. & $\cdot, \wedge \leq r$ & $r, r$. & r, & $r, \ldots$ & $\varepsilon 1$ \\
\hline גז,r & $\cdot, q \vee V$ & $r, Y V$ & $\cdot, 91 \vee$ & $r, \wedge r$ & $\varepsilon r$ \\
\hline$\bullet, \vee 0$. & $\cdot, v \cdot r$ & 1,94 & צזדו, & r,or & $\varepsilon r$ \\
\hline ד & $\cdot, \mathrm{V} \leqslant \Lambda$ & $1, \wedge \wedge$ & $\cdot, 7 \cdot 1$ & $r, \diamond q$ & $\varepsilon \varepsilon$ \\
\hline$\cdot, 11 r$ & $\cdot, v \cdot I$ & $r, r_{1}$ & $\cdot, v \cdot \varepsilon$ & $r, r r$ & $\varepsilon 0$ \\
\hline$r, \leq \uparrow$. & 1,004 & 1,71 & $1, .10$ & $r, r$. & $\varepsilon 4$ \\
\hline$\bullet, V \vee$. & $\cdot, v \cdot r$ & $1, V \varepsilon$ &., $7 \circ 1$ & $r, r q$ & $\varepsilon V$ \\
\hline$\bullet, 0 \wedge q$ & $\cdot, v \cdot \Lambda$ & $r, \varepsilon Y$ & צ & $r, q r$ & $\varepsilon \wedge$ \\
\hline $0, \Delta r q$ & $\cdot, V \leq V$ & $r, r q$ & $\cdot r \leqslant 0$ & $r, \wedge \uparrow$ & $\varepsilon q$ \\
\hline $0, r \vee \checkmark$ & •, & $r, \varepsilon V$ & . & $r, 90$ & 0 . \\
\hline$r, O \wedge 0$ & •, & $r, I r$ & $1, \ldots 1$ & $r, v r$ & 01 \\
\hline $0, \Sigma \vee V$ & $\cdot, \vee \vee \neg$ & $1, \wedge 0$ & $\cdot, v \leq \varepsilon$ & $r, 01$ & or \\
\hline$r, \varepsilon q \wedge$ &,$V Y I$ & $r, Y_{T}$ & $\cdot, 09 \varepsilon$ & $r, O r$ & or \\
\hline$\uparrow, \varepsilon \vee \diamond$ &,$\quad \vee v \leqslant q$ & $r, \cdot \varepsilon$ &., 017 & $r, 79$ & 0\{ \\
\hline$r, \varepsilon \leqslant 1$ & $\cdot, v \otimes \Delta$ & $r, Y_{T}$ & $\cdot$, VYo & $r, 0 \leq$ & 00 \\
\hline
\end{tabular}


مجلة جامهة بابل، الهلوم الإنسانية، المجلد רج، الهدد T: M|.P Journal of University of Babylon, Humanities, Vol.(26), No(6): 2018

\begin{tabular}{|l|l|l|l|l|l|}
\hline, $9 r \varepsilon$ & $\cdot, \wedge r r$ & $r, 10$ &., $7 \wedge 0$ & $r, r \uparrow$ & $0 \%$ \\
\hline
\end{tabular}

r - طريقة الاتساق الداخلي للفقرات:

يعد هذا الاسلوب من اكثر الاساليب استخداما في تحليل فقرات المقاييس النفسية, وان ارتباط الفقرة بالدرجة الكلية للمقياس يعني ان الفقرة تقيس الدفهوم الذي تقيسه الدرجة الكلية, و المقياس الذي تنتخب فقر اته

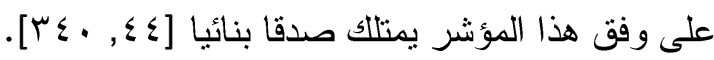

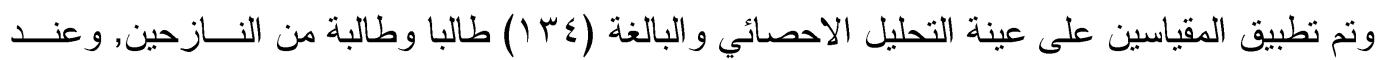
حساب معامل الارنباط بين درجة كل فقرة و الدرجة الكلية وباستعمال معامل ارتباط (بيرســـون) اتضــــح ان

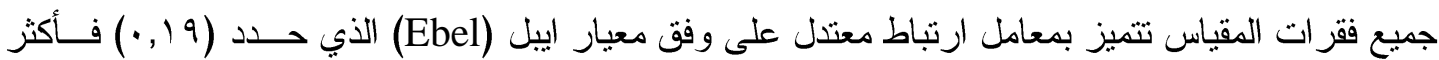

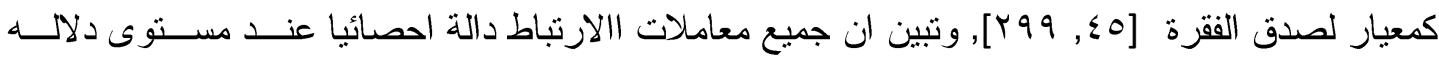

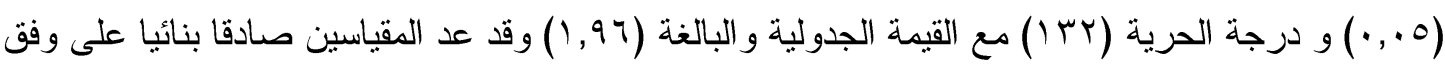

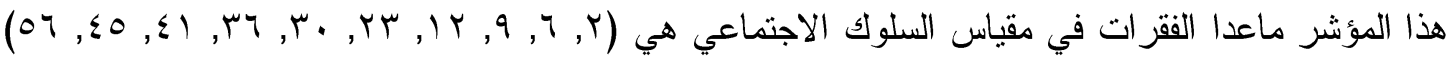

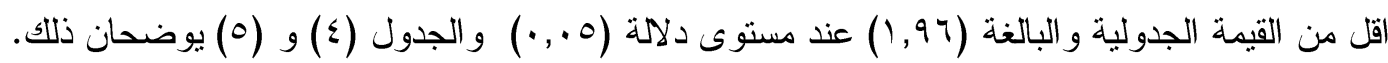

جدول (ء)قيم معاملات ارتباط الفقرة بالدرجة الكلية لمقياس التنمر

\begin{tabular}{|c|c|c|c|}
\hline معامل ارتباط الفقرة بالارجة الكلية & الفقرة & معامل ارتباط الفقرة بالدرجة الكلية & الفقرة \\
\hline.,$\circ \mathrm{V}$. & 11 & • rAr & 1 \\
\hline ו וזד, & ir & $\cdot, r \leq r$ & r \\
\hline$\cdot, 0 \wedge 1$ & ir &., $\mathrm{OV}$ & $r$ \\
\hline$\cdot, \leqslant \wedge \vee$ & $1 \varepsilon$ & $\cdot, \varepsilon r q$ & $\varepsilon$ \\
\hline$\cdot, \circ \vee \varepsilon$ & 10 & $\cdot, \leqslant 1 \leqslant$ & $\bullet$ \\
\hline ., & 17 & $\cdot, r v \cdot$ & 7 \\
\hline., 0.0 & iv & • & $v$ \\
\hline דוr, - & 11 &., $01 \leqslant$ & $\wedge$ \\
\hline$\cdot, \leqslant \mu q$ & 19 & $\cdot, r$. & 9 \\
\hline$\cdot r \leqslant r$ & $r$. & $\cdot, r \wedge v$ & 1. \\
\hline
\end{tabular}


مجلة جامهة بابل، الهلوم الانسانية، المجلد רج، العدد T: MIاיP Journal of University of Babylon, Humanities, Vol.(26), No(6): 2018

جدول (ه) قيم معاملات ارتباط الفقرة بالدرجة الكلية لمقياس السلوك الاجتماعي

\begin{tabular}{|c|c|c|c|c|c|}
\hline علاقة الفقرة بالدرجة الكلية & الفقرة & علاقة الفقرة بالدرجة الكلبة & الفقرة & علاقة الفقرة بالدرجة الكلية & الفقرة \\
\hline . TrV & rq & ., or. & $r$. & ז4ו,. & 1 \\
\hline . r rvo & $\varepsilon$. & מתt, & ri &., $10 \mathrm{~V}$ & $r$ \\
\hline ., , ११ & \&1 & ., , & rr & . & $r$ \\
\hline .,$\leqslant 90$ & $\varepsilon r$ & r.,., & rr & דצ ז, . & $\varepsilon$ \\
\hline$\cdot, 7.9$ & $\varepsilon r$ & P THY & $r \varepsilon$ & שTY, & 0 \\
\hline ו & $\varepsilon \varepsilon$ &., $0 . r$ & ro & $1, r q$ & 4 \\
\hline צו17, & $\leq 0$ & , , & דיץ & . & v \\
\hline., 04. & $\varepsilon 4$ & • & TV & •, YAV & $\wedge$ \\
\hline .,095 & $\varepsilon V$ & V४ & $r \wedge$ & . & 9 \\
\hline$\cdot$, rA. & $\varepsilon \Lambda$ & •, $\{01$ & rq & צדו, • & 1. \\
\hline דry, & $\varepsilon 9$ & . & r. & $\cdot, 190$ & 11 \\
\hline 000, & 0. & ז4 & r &., 10 & ir \\
\hline צדוח, , & 01 & ., $\leqslant$ \&. & rr & , r. & ir \\
\hline 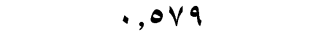 & or & r r r r & r & । & $1 \varepsilon$ \\
\hline - & or & 4T, & $\Gamma \varepsilon$ & •,$r \leqslant$. & 10 \\
\hline •, $71 \wedge$. & $0 \leqslant$ & סוז, • & ro & - roq & 17 \\
\hline -,$\leqslant \wedge 0$ & 00 & $\cdot, 1 \leqslant r$ & 4 & •, r & IV \\
\hline $1, \varepsilon 1$ & 04 & -,$\leqslant q$. & rV & יוד & 11 \\
\hline- & - & .,ONT & rA & ש & 19 \\
\hline
\end{tabular}

الخصائص السايكومترية لمقياس التنمر والسلوك الاجتماعي:

ا- الصدق المقياس(Vealer Validity): طبق الباحث نوعين من الصدق للمقياس الحــالي هــــا : الصــدق الظاهري (Face Validity) وصدق البناء (Constrict Validity).

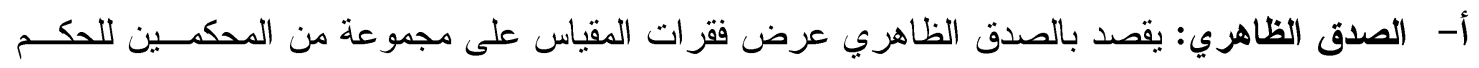

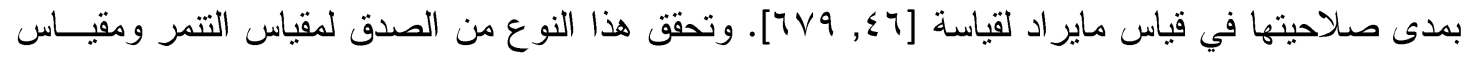
السلوك الاجتماعي في البحث الحالي عن طريق عرضهما على مجموعة من المحكمين المتخصصـين فـي مني مجال علم النفس التزبوي و القياس و التقويم للحكم على صلاحيتها. 
ب- صدق البناء: يقصد به تحليل درجات المقياس في ضوء مفهوم نفسي معين استتادا الى الخاصية المــراد

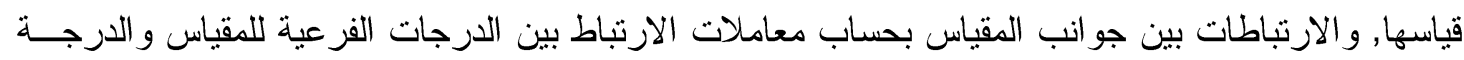

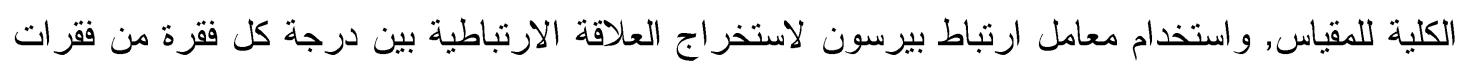

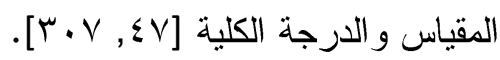

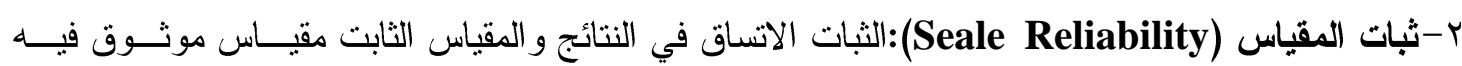
ومعتمد عليه, يعطي النتائج نفسها, ودرجات المقياس تكون ثابتة اذا كان المقياس يقبس سمة معينة قياسا متسقا

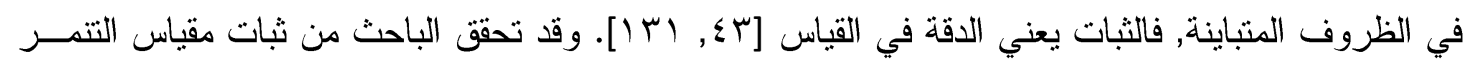
ومقياس السلوك الاجتماعي بالطر ائق الاتية: أ- طريقة اعادة الاختبار (Re - Test): نستتد الفكرة الاساسية في هذه الطريقة الى اجر اءع الاختبار علـى الفى

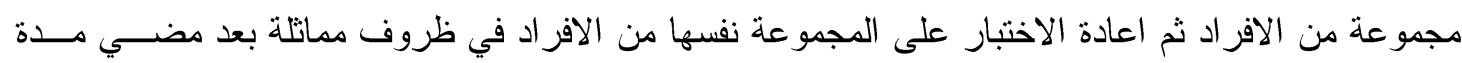

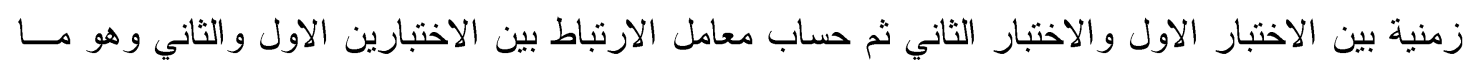

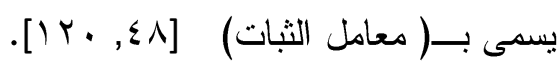
وقد طبق الاختبار على عينة مكونة من (·r) طالبا اختيروا عشو ائيا, وبعد مرور (10) يوما طبق

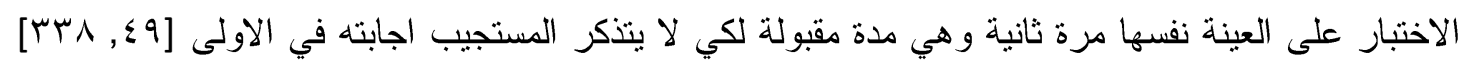

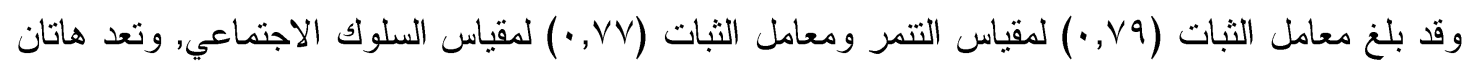

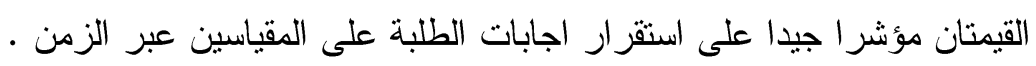

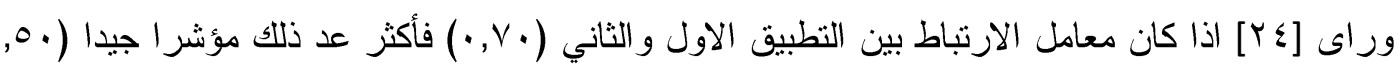

ب- معادلة الفا كرونباخ (Coefficient Alfa): اثنق كرونباج صورة عامة لمعادلة الثبات علــى اســاس

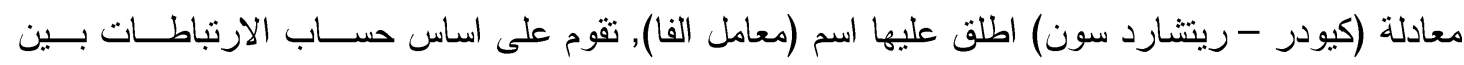

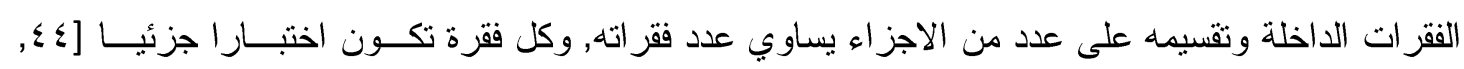

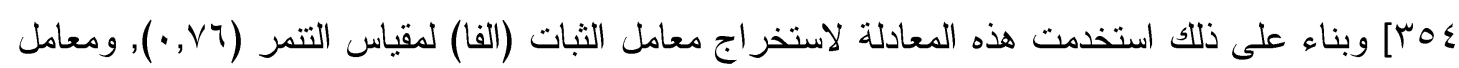

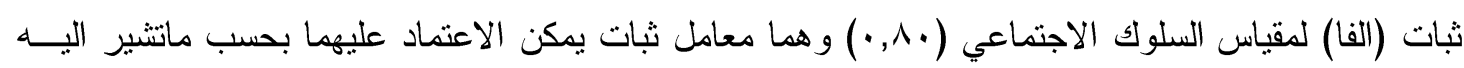

\section{وصف مقياس التنمر ومقياس السلوك الاجتماعي بصيغتهما النهائية:}

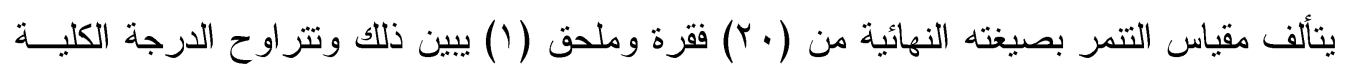

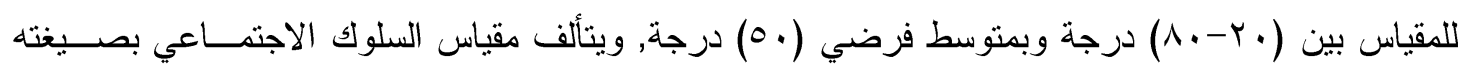

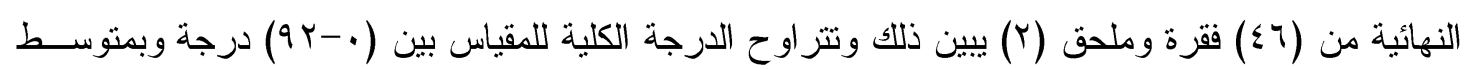




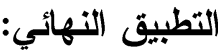

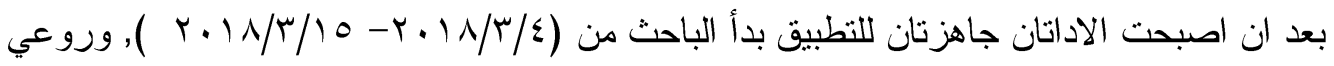

ان يجرى تطبيق اداتي البحث على العينة في ظروف جيدة من حيث التهوية و الاضـاءة و الجلســة المريحــة,

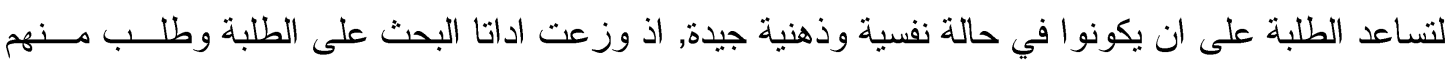
تدوين البيانات على ورقة الاجابة.

وبعد شرح الباحث كيفية الاجابة عن فقرات الاداتين و اعطائهم مثالا على ذلك, وتم اعلامهم ان اجابـاتهم

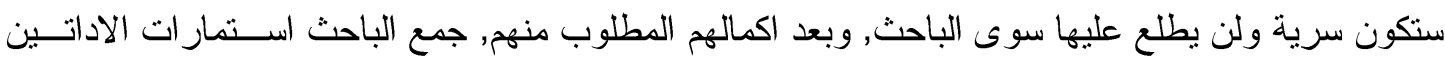

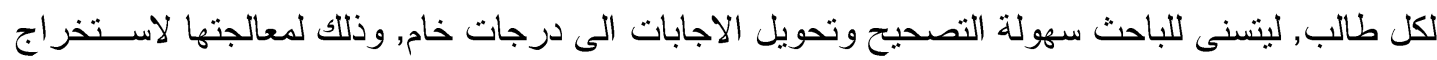

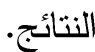

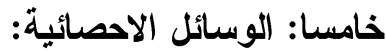

لغرض تحقيق اهداف البحث الحالي استعملت الوسائل الاحصائية المناسبة في هذا البحث بالاستعانة بالبرنامج الاحصائي (SPSS) وكما يأتي:

1-معامل ارتباط بيرسون: ايجاد العلاقه الارتباطية بين مقياس التتمر ومقياس السلوك الاجتمــاعي, و ايجــاد العلاقة الارتباطية بين درجة كل فقرة و الدرجة الكلية للمقياسين. ץ-الاختبار التائي ( T-Test): لعينة واحدة لاختبار الفرق بين المتوسط الحسابي لدرجات العينة على مقاييس البحث و المتوسط الفرضي. الإخئ.

ب-الاختبار التائي (T-Test): لعينتين مستقلنين لتحقيق لاختبار الفروق بين متوسط درجات المجموعة العليا و المجموعة الدنيا و لاستخر اج القوة التمييزية لفقرات المقياسين. ع -معادلة الفا كرونباخ: لاستخر اج الثبات بطريقة الاتساق الداخلي للمقياسين. الفصل الر ابع/ عرض النتائج وتفسيرها ومناقشتها

يتضمن هذا الفصل عرضـا للنتائج التي توصل اليها الباحث على وفق اهدافه المحددة وتفسير هــذه

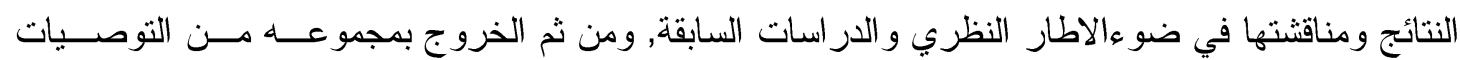
و المقترحات بناء على تلك النتائج, وفيما يلي عرض وض نتائج البحث: ا-التعرف على مستوى التنمر لاى الطلبة:

لاجل تحقيق هذا الهدف جمع الباحث البيانات وتفريغها في برنامج الحقيبة الاحصائية (SPSS) ظهـر

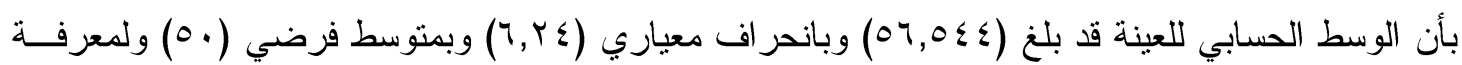

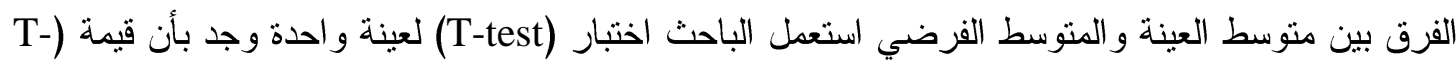

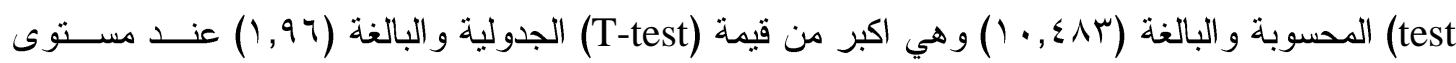

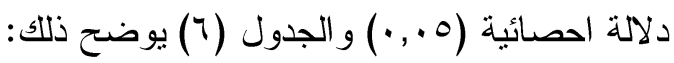


مجلة جامهة بابل، الهلوم الانسانية، المجلد רب، الهدد T: M|.P Journal of University of Babylon, Humanities, Vol.(26), No(6): 2018

جدول (†) القيمة التائية لدلالة الفروق على مقياس التنمر

\begin{tabular}{|c|c|c|c|c|c|c|}
\hline مستوى الدلالة & \multicolumn{2}{|c|}{ القيمة التائية } & الأحر اف & الوسط الفرضي & الوسط الحسابي & حجم العينة \\
\hline \multirow[t]{2}{*}{ دالة } & الجدولية & المحسوبه & \multirow[t]{2}{*}{$Y, Y \varepsilon$} & \multirow[t]{2}{*}{0 . } & \multirow[t]{2}{*}{$0 Y, 0 \leqslant \varepsilon$} & \multirow[t]{2}{*}{$1 \pi \varepsilon$} \\
\hline & 1,97 & $1 \cdot, \varepsilon \wedge \mu$ & & & & \\
\hline
\end{tabular}

يتضح من الجدول (7) ان عينة البحث لديها مستوى مرتفع من التتمر لان الوسط الحسابي أكبـر مــن

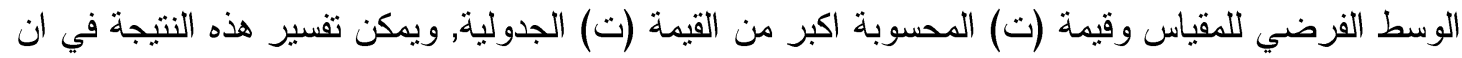
افر اد عينة البحث لديهم مستوى مرتفع من التنمر ذلك لان عينة البحث هم من طلبة المرحلة المتوسطة وهذه المرحلة تحتاج الى شعور الطالب بالحب والانتماء الذي يعد من الحاجات الانسانية المهمة التي يتم منها اشباع

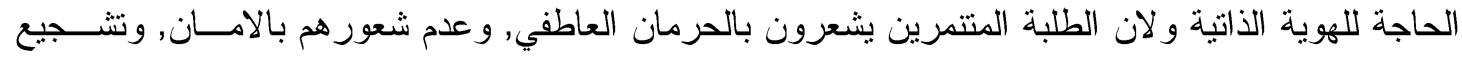
الاهل الابن على ضرب من يضربه, مشاهدة افلام العنف, تساهل ادارة المدرســة فــي اتخــاذ الاجـر اءعات النظامية ضد المتتمرين وللتتمر اثكال (جسدي, عاطفي, اللفظي, الجنسي), وتتفق هذه الدراسة مــع دراســة ( Conoolly \& OMoore,2003 )

r-التعرف على مستوى السلوك الاجتماعي لاى الطلبة:

لاجل تحقيق هذا الهدف جمع الباحث البيانات وتفريغها في برنامج الحقيبة الاحصائية(SPSS) ظهر بأن

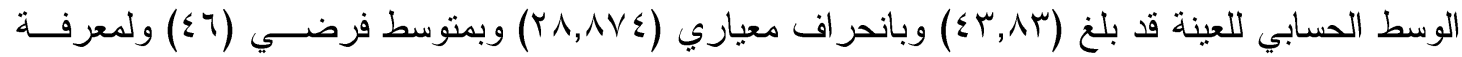
الفرق بين متوسط العينة و المتوسط الفرضي استعمل الباحث اختبار (T-test) لعينة واحدة وجد بأن قيمة (العينة (test احصائية (0., · ) و الجدول (V) يوضح ذلك:

جدول(V) القيمة التائية لالالة الفروق على مقياس السلوك الاجتماعي

\begin{tabular}{|c|c|c|c|c|c|c|}
\hline مستوى الدلآةه . , . & \multicolumn{2}{|c|}{ القيمة التائبة } & الأحر اف & الوسط الفرضي & الوسط الحسابي & حجم العينة \\
\hline \multirow[t]{2}{*}{ غير دالة } & الجدولية & المحسوية & \multirow[t]{2}{*}{$r \wedge, \wedge \vee \varepsilon$} & \multirow[t]{2}{*}{$\varepsilon q$} & \multirow[t]{2}{*}{$\varepsilon r, \wedge r$} & \multirow[t]{2}{*}{ Irs } \\
\hline & 1,97 & $1, v \otimes V$ & & & & \\
\hline
\end{tabular}

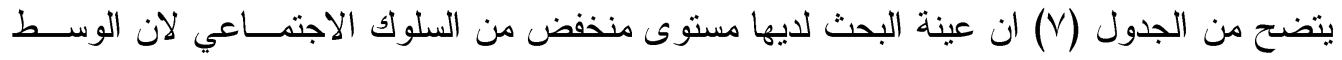

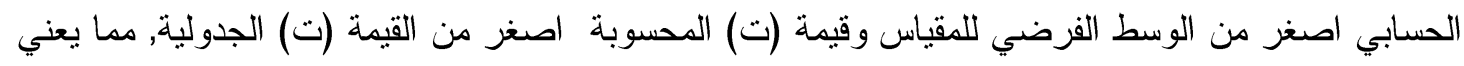

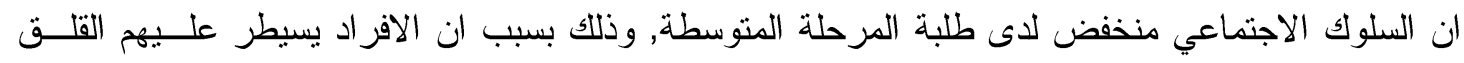
و التونز و الاحباط يعجزون من اقامة علاقات اجتماعية مع الاخرين التي تقوم على التقة والتقبل و التقهم, ولهذا 
Journal of University of Babylon, Humanities, Vol.(26), No(6): 2018

تضعف قدرتهم على الاخذ و العطاء وتتحصر في حدود ضيقة [1, 190] 190 و لاتتفق مع دراسة[1] بأن طلبة يتمتعون بالسلوك الاجتماعي المرغوب به.

r-العلاقة بين التنمر والسلوك الاجتماعي لاى الطلبة في المرحلة المتوسطة: لأجل تحقيق هذا الهدف

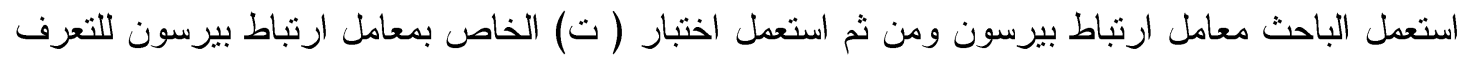
على دلالة الفروق في العلاقة الارتباطية بين المتغيرين وحصل على النتائج المبينة في الجدول: جدول(^) جدول بيين العلاقة الارتباطية بين التنمر والسلوك الاجتماعي

\begin{tabular}{|c|c|c|c|c|c|c|}
\hline مستوى دلالة & درجة & \multicolumn{2}{|c|}{ القيمة التائية } & قيمة معامل & حجم & المتفير \\
\hline \multirow[t]{2}{*}{., .0} & \multirow[t]{2}{*}{ Irr } & الجدولية & المحسوبة & \multirow[t]{2}{*}{$\cdot, \varepsilon r$} & \multirow[t]{2}{*}{ } & \multirow{2}{*}{ الالتمر × السلوك } \\
\hline & & 1,97 & $r, o r$ & & & \\
\hline
\end{tabular}

تبين من الجدول اعلاه وجود علاقة ارتباطية بين التتمر و السلوك الاجتماعي لدى طلبــة المرحلـــة المتوسطة اذ بلغت قيمة معامل ارتباط بيرسون (بّع, •) وبعد اختبارها باستعمال اختبار (ت) الخاص بمعامل

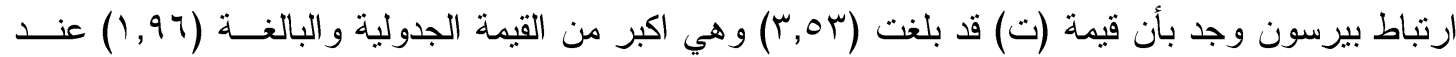

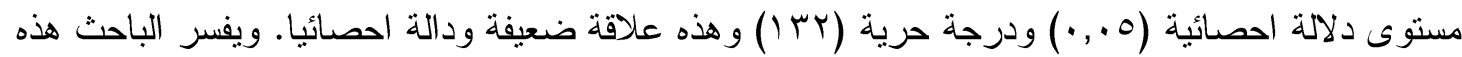
النتيجة بأن التتمر ظاهرة بدأت باتساع بالمدارس ويعود الى التتشئة الاجتماعية الخاطئة اذ ان اسلاليب التوجية

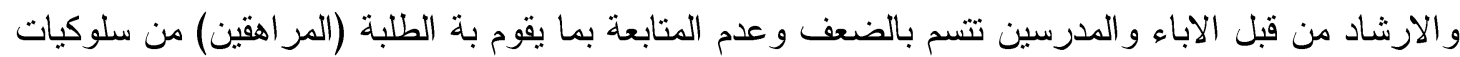

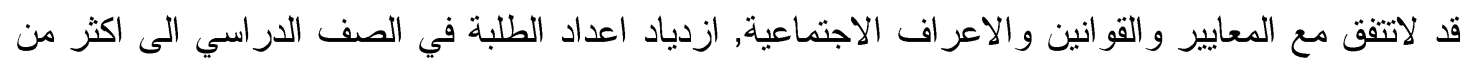

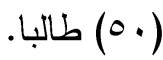

الاستتتاجات: على ضوء نتائج البحث الحالي, استتنج الباحث ما يأتي: 1-ان طلبة المرحلة المتوسطة يعانون من مستوى مرتفع من التتمر . r-انخفاض مستوى السلوك الاجتماعي لاى طلبة المرحلة المتوسطة.

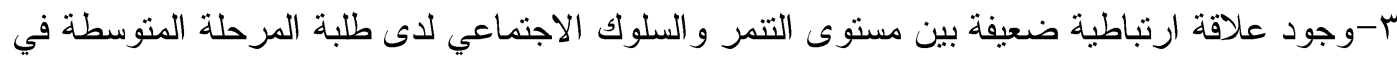

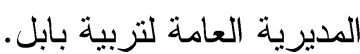
التوصيات: على ضوء نتائج البحث الحالي, يوصي الباحث بما يلي: 1-ضرورة متابعة الطلبة المتنمرين باجر اء بر امج واختبار ات علمية حديثة لمعرفة مستوى التتمر لديهر, وتوجيهـ بالحلول المناسبة و التخفيف من اثار ها.

r-اعداد دليل للمدرسين لنشخيص الطلبة المتتمرين و ايجاد السبل اللازمة لدرء التتمر في المدرسة.

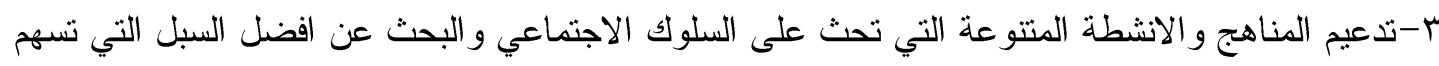
في تتميتها وتطوير ها. ع--عمل برامج تدريبية لتوعية المدرسين بالتنمر المدرسي وكيفية التعامل معه. 
Journal of University of Babylon, Humanities, Vol.(26), No(6): 2018

$$
\text { 1-الاهتمام بالبر امج التربوية التزبويين لمساعدة الطلبة المتتمرين عن طريق الارشاد التربوي (الفردي, الجمعي). }
$$

استكمالا للجو انب ذات العلاقة بهذا البحث بتقدم الباحث بالمقترحات الاتية:

1- التنمر و علاقته بالصحة النفسية لدى طلبة المرحلة الثانوية.

r- التتمر وعلاقته بدافعية الانجاز لاى طلبة المرحلة الاعدادية.

ب- السلوك الاجتماعي وعلاقته بتقدير الذات لدى طلبة المرحلة الثانوية.

ع - السلوك الاجتماعي وعلاقته انماط التفضيل المعرفي لدى طلبة الجامعه.

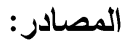

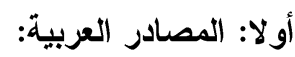

ا ـ خوج, حنان اسعد: التنمر المدرسي وعلاقته بالمهارات الاجتماعية لدى تلاميذ المرحلة الابتدائية بمدينة جدة

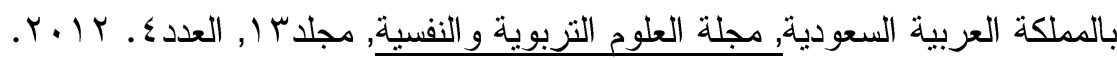

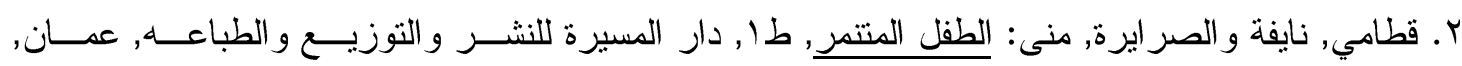

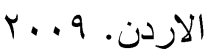

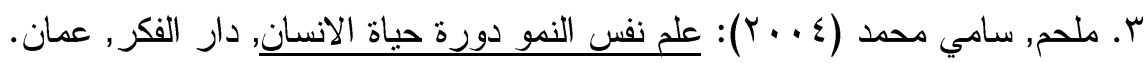

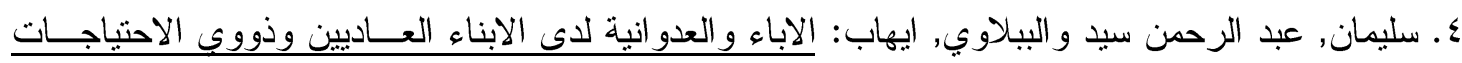

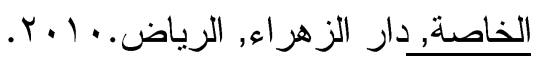

ه. منسي, محمود عبد الحليم: عمل الام و السلوك الاجتماعي للابناء من تلاميذ المرحلة الابتدائيــة بالمدينــة المنورة, مجلة العلوم الاجتماعية, عددء, الكويت.

7. الخزرجي, سناء صاحب: التغير الاجتماعي وسلوك الطالبة الجامعية, رسالة ماجستير (غير منشورة) كلية الاداب, جامعة بغداد. 1997

V. شو ان, محمد عبد الله: بناء مقياس مقنن للسلوك الاجتماعي لدى طلبة الجامعــهـ فــي العـراق, اطروحــــ

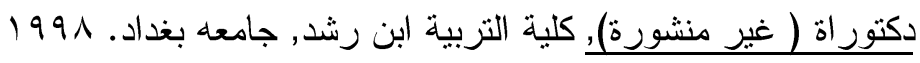

^. ذيب, ايمان عبد الكريم: السلوك الاجتماعي للطالب الجامعي, مجلة مركز البحوث التزبوية و النفسية, العدد

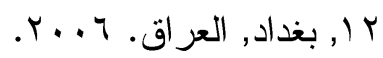

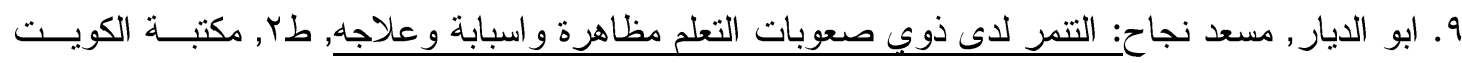

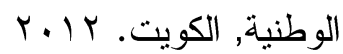

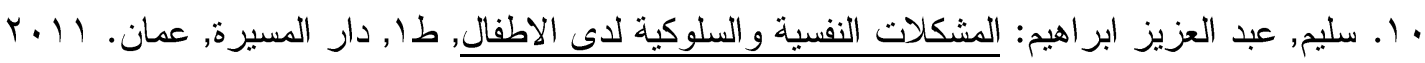

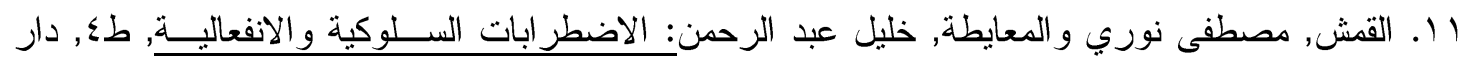

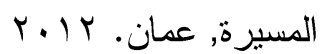

12. O. Morrison,: Education and Development of infants Toddlers and Preschools. Scott forseman and Co. 1988. 
Journal of University of Babylon, Humanities, Vol.(26), No(6): 2018

با ـ. التميمي, سميعة علي حسن: اثز اسلوب النمذجة في تتمية المهار ات الاجتماعية لدى اطفــال الروضـــــ

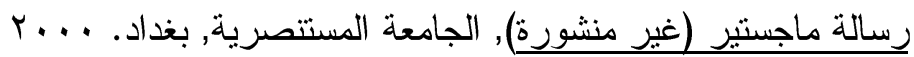

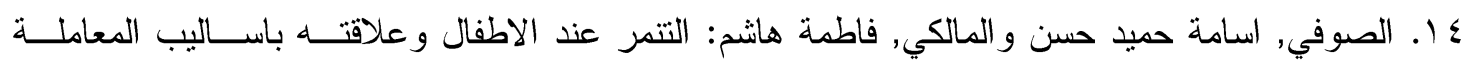

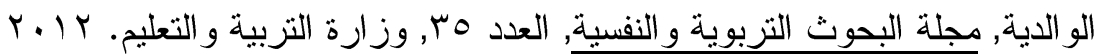
15. A. Bandura, Principles, of Behavior Modification. Newyork Holt Reinhart Winston. 1969.

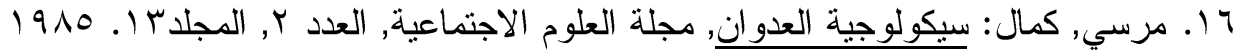
17. Smith, S., Kids hurting kids: Bullies in the schooiyard Mothering Magazine, 7 (12) , 43-59. 2001.

1 ا. عبد العظيم, طه: سيكولوجية العنف, المفهوم, النظرية, العلاج, دار الصولتية للنشر والتوزيع, الريــاض,

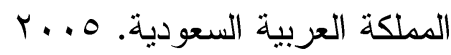

9 19. زهران, حامد عبد السلام: علم النفس الاجتماعي, طع, عالم الكتب, القاهرة. I9VV

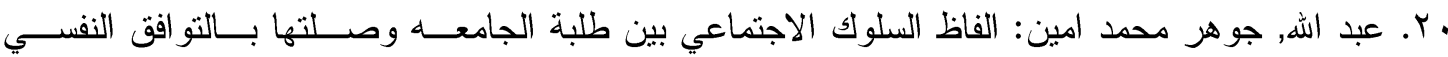

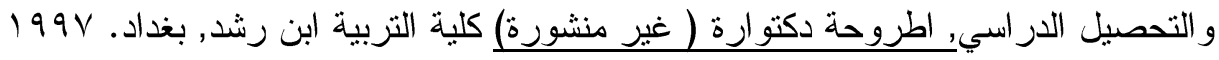
ا r. دكت, جون: علم النفس الاجتماعي و التعصب, ترجمة عبد الحميد صفوت, دار الفكر العربي, القــاهرة. r...

ז r. دافيدوف, لندال: مدخل علم النفس, ترجمة نجيب خزام وفو اد ابو حطب, الــدار الدوليــة للاســتـمارات

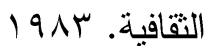

بr. هول, كى ولندزي ج: نظريات الثخصية, ترجمة فرج احمد فرج واخرون, الهيئة المصــرية العامــة للتاليف و النشر , القاهرة. I9VV

ع r. السيد, فؤاد البهي وسعد عبد الرحمن: علم النفس الاجتماعي ( رؤية معاصـرة), دار الفكـر العربــي,

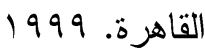

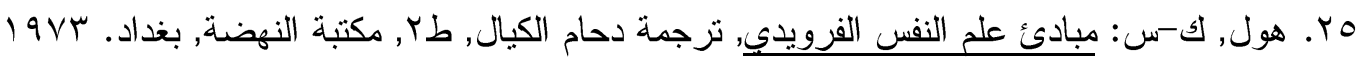

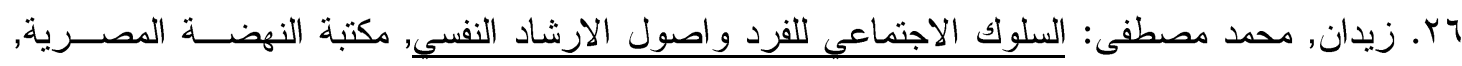

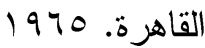

V V. الكبيسي, و هيب مجيد وصالح حسن الداهري: المدخل في على النفس التربوي, طا, دار الكندي للنشـر

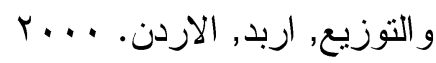

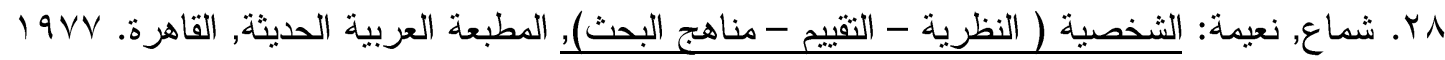
9 r. جلال, سعد(): المرجع في علم النفس, دار الفكر العربي, القاهرة. 1910 • ب. البيلي, محمد عبد الله واخرون (): علع النفس التربوب وتطبيقاته, مكتبة فلاح للنشر و التوزيع, جامعسة

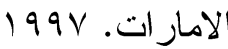

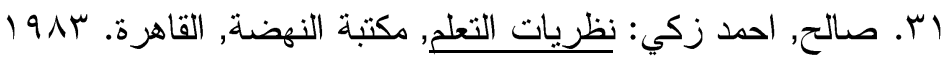
r r.. الازيرجاوي, فاضل محسن: اسس علم النفس الثربوبي, دار الكتب للطباعة و النشر , جامعــة الموصــلـ. 
Journal of University of Babylon, Humanities, Vol.(26), No(6): 2018

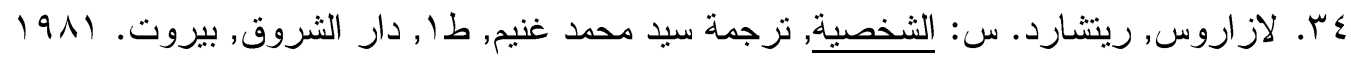

$$
\begin{aligned}
& \text { هب. جادو, عبد العزيز (ب ت ت): الشعور و اللاشعور, المكتب الجامعي الحديث, الاسكندرية. }
\end{aligned}
$$

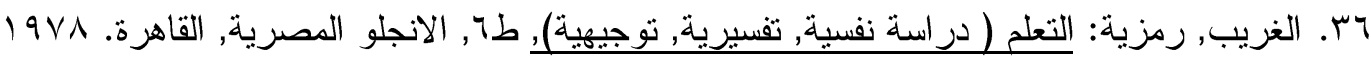
VIr. أبو عطية, سهام درويش: الارشاد النفسي والتربوي, المطبعة العربية للنشر والتوزيع, عدئسان, الاردن. $199 V$

^ץ.. الموسوي, عباس نوح سليمان (): السلوك الاجتماعي وعلاقته بالثعور بالذات والامن النفسي لدى طلبة

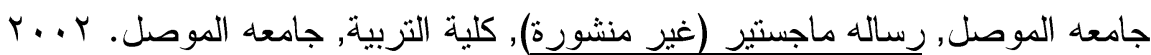
39. Connely, \& O'Moore, Personality and Family Relation of children who bully. Personality \& Individual Differences. 35(3). 559-567. 2003

• ــ داود, عزيز حنا, وعبد الرحمن, انور حسين: مناهج البحث التربوي, كلية ابن رشــد, جامعسة بغـــاد.

اء. عودة, احمد سليمان, وملداوي, فتحي حسن: اساسيات البحث العلمي في التزبية و العلوم الانســانية, طـا, مكتبة الكناني, الاردن.

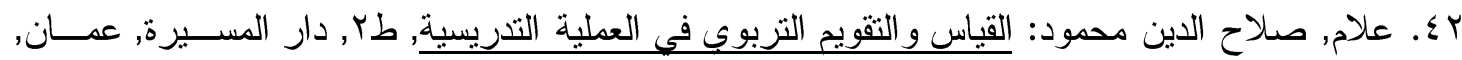

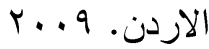

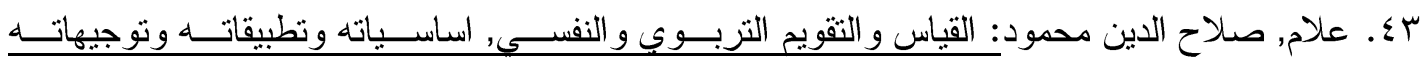

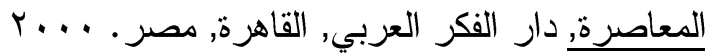

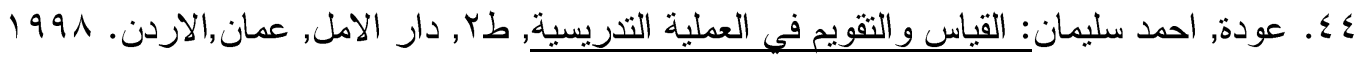
45. Ebel, Robert $1 \&$ Frisbile, david. A, Essentials of educational measurement 5ed PHL L earning Private Limited, New Delhi. 2009

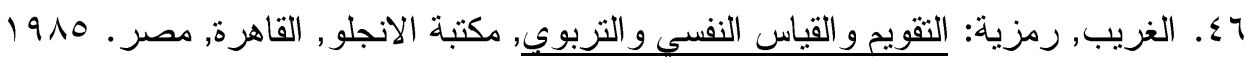
V V. حبيب, مجدي عبد اله كريم: التقويم و القياس في التربية وعلم النفس, طا , مكتبة النهضة, القاهرة, مصر.

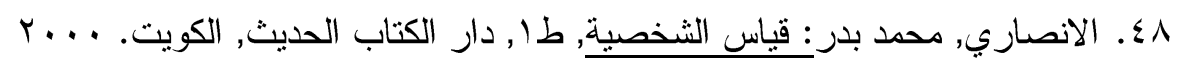

9 ـ. ايرفن, لهمن, ووليم, مهز انز: القياس و التقويم في التزبية وعلم النفس, طا, ترجمة ماهر ابو هالة, دار

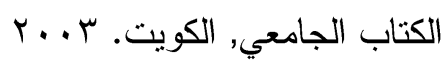

• ه. العيسوي, عبد الرحمن محمد: القياس و التجريب في علم النفس و التربية, دار المعرفة, القاهرة, مصر . 